\title{
Profiting from Regulation: Evidence from the European Carbon Market
}

\author{
By James B. Bushnell, Howard Chong, And Erin T. Mansur**
}

We investigate how cap-and-trade regulation affects profits. In late April 2006, the $\mathrm{EU} \mathrm{CO}_{2}$ allowance price dropped 50 percent, equating to a $€ 28$ billion reduction in the value of aggregate annual allowances. We examine daily returns for 552 stocks from the EUROSTOXX index. Despite reductions in environmental costs, we find that stock prices fell for firms in both carbon-and electricity-intensive industries, particularly for firms selling primarily within the EU. Our results imply that investors focus on product price impacts, rather than just compliance costs and the nominal value of pollution permits. (JEL G12, G14, L94, Q53, Q54, Q58)

T here is a long-standing perception of a fundamental conflict between the interests of business and environmental regulators. In many cases regulators apply policies that increase production costs, restrict production, or otherwise constrain the actions of firms. There is a rich literature chronicling the impacts that regulations such as the Clean Air Act have had on industrial activity..$^{1}$ With greenhouse gas regulation a controversial subject in the United States and already under way in the European Union (EU), the question of the impacts of these regulations on industry has taken center stage. As countries and regions around the world develop policies for limiting greenhouse gas $(\mathrm{GHG})$ emissions, there is an understandably great interest in how these policies will impact the competitiveness, productivity, and profitability of the industries to which they are applied.

Measuring the economic impacts of GHG regulations obviously has direct relevance to setting the levels and timings of the regulations. Even setting aside the specific goals for GHG reductions, information about the overall magnitude and distribution of economic impacts has importance for the policymaking process. This is most starkly true in the case of cap-and-trade mechanisms, which create valuable new property rights in the form of emissions allowances (or permits).

\footnotetext{
* Bushnell: University of California at Davis, Economics Department, 1126 SSH, One Shields Avenue, Davis, CA 95616 and National Bureau of Economic Research (NBER) (e-mail: jbbushnell@ucdavis.edu); Chong: Cornell University, School of Hotel Administration, 545C Statler Hall, Ithaca, NY 14853-6902 (e-mail: hc757@cornell. edu); Mansur: Dartmouth College, Economics Department, 6106 Rockefeller Hall, Hanover, NH 03755 and NBER (e-mail: erin.mansur@dartmouth.edu). The authors are grateful for helpful discussion and comments from Antonio Bento, Denny Ellerman, Nat Keohane, Matt Kotchen, Arik Levinsohn, Mar Reguant, and seminar participants at Environmental Defense Fund, Georgetown, Harvard, Minnesota, UC Berkeley, UC Davis, MIT, and Yale University.

${ }^{\dagger}$ Go to http://dx.doi.org/10.1257/pol.5.4.78 to visit the article page for additional materials and author disclosure statement(s) or to comment in the online discussion forum.

${ }^{1}$ For example, see Gray (1987); Gray and Shadbegian (1998); Greenstone (2002); Becker and Henderson (2000); and List, Millimet, and McHone (2003).
} 
These permits constitute the "currency" of cap-and-trade markets. They also provide an important tool to policymakers for distributing the revenues collected by the carbon regulation. The process of allocating emissions allowances, while inevitably containing a strong element of political maneuvering, is usually driven by a desire to offset some of the cost impacts of the introduction of carbon regulation. Industries that claim to bear the brunt of the abatement costs usually stake the largest claim to allocations of allowances.

However, for most industrial enterprises, changes in direct abatement costs are only one piece of a complicated profitability puzzle. The introduction of a carbon dioxide $\left(\mathrm{CO}_{2}\right)$ price into an economy can have indirect impacts on firms that are not large $\mathrm{CO}_{2}$ emitters. In most industries, increases in pollution prices will be reflected in output prices, and therefore revenues, as well as in costs. A more complete picture of these net impacts is necessary in any attempt to align allocations to the true economic impacts of $\mathrm{CO}_{2}$ regulation on firms.

Indeed, the impact of regulations on profitability is ambiguous, even when those regulations have a substantial impact on costs. There are several mechanisms, ranging from restricting entry (e.g., Ryan 2012) to raising rivals' costs (e.g., Puller 2006), through which revenue increases can outstrip cost increases thus enhancing profitability. ${ }^{2}$ With cap-and-trade regulations, the free allocation of emissions allowances adds an additional source of revenue. In the case of GHG markets, these assets can total hundreds of billions of dollars.

Despite the politically motivated tendency to award emissions allowances proportionally to emissions, several papers have concluded that this likely amounts to overcompensation of the affected industries. These papers use various simulation methodologies to forecast potential impacts of carbon taxes or caps. Bovenberg and Goulder (2001) and Goulder, Hafstead, and Dworsky (2010) utilize general equilibrium models to assess the likely impacts of a carbon tax and various cap-and-trade policies on a wide set of industries. Burtraw and Palmer (2008) simulate the US electricity sector under potential cap-and-trade scenarios. Smale et al. (2006) simulate several industries under a carbon cap in Europe using an assumption of Cournot competition. All these studies find that for many industries, compensation of less than 20 percent of emissions would offset the profitability impacts of regulation.

In this paper we study impacts on firms of the largest, in monetary terms, capand-trade market in the world - the EU's Emissions Trading System (ETS) for $\mathrm{CO}_{2}$. To date, this is the most significant effort by far at regulating $\mathrm{CO}_{2}$ emissions in the world. As a role model for carbon cap-and-trade, the ETS has been closely scrutinized both within and outside the European Union. From the outset, the relative impact of the ETS on EU industries has been a controversial topic, one that has strongly influenced policies for the allocation of emissions allowances. During its first phase of operation from 2005 through 2007, the prices of emissions allowances in the EU market were quite volatile. While this volatility sparked criticism about

\footnotetext{
${ }^{2}$ For example, Ryan (2012) demonstrates how the Clean Air Act significantly increased the sunk cost of entry in the Portland cement industry. Puller (2006) demonstrates how firms can profit from increased regulation by raising rival's costs, leading them to promote the adoption of those regulations.
} 
the design and implementation of this phase of the market, we take advantage of it in order to examine the impact of $\mathrm{CO}_{2}$ prices on firms.

Rather than attempting to directly untangle the many competing effects of the ETS on firms, we focus on the stock market valuations of publicly traded firms influenced by $\mathrm{CO}_{2}$ regulation. Specifically, we examine the impact of a sharp devaluation in $\mathrm{CO}_{2}$ prices in late April 2006 as an event study on the share prices of affected firms. Such an exercise can be interpreted in several ways. Under an assumption of fundamental market valuation, these prices should reflect the market's expected discounted future profits of the firms. Even if one does not adhere to an assumption that the market fully reflects expectations of future profitability, the event provides a useful window into the beliefs of the market about the impacts of movements in $\mathrm{CO}_{2}$ prices.

Our results imply that several industrial sectors benefited from the ETS rather than being hurt by the imposition of $\mathrm{CO}_{2}$ regulation. Indeed, when $\mathrm{CO}_{2}$ prices fell (a relaxation of regulation), the sharpest declines in equity prices occurred within industries that are the most carbon-intensive. In addition to raising costs, $\mathrm{CO}_{2}$ regulation can "pass-through" to affect the prices of the goods sold and firm revenue. In some cases, unregulated or less-regulated firms in regulated industries may benefit from the regulation. The stock market response to the April event indicates that $\mathrm{CO}_{2}$ prices play a significant role in determining product prices and revenues in many of these industries, and that this revenue effect may dominate costs for those industries. We also examine the stock market price responses relative to a measure of European market exposure and find strong evidence that the benefits of higher $\mathrm{CO}_{2}$ prices were concentrated among firms with the most exposure to markets within the EU.

In Section I, we briefly review the $\mathrm{EU} \mathrm{CO}_{2}$ market and its pricing from 20052007 and examine the impact of the crash in permit prices in late April 2006 using a stock market event study. In Section II, we develop a simple model of the channels through which $\mathrm{CO}_{2}$ costs can impact firm profitability. In Section III, we empirically decompose the underlying impact to elements of firm and industry characteristics that influenced the response to the change in $\mathrm{CO}_{2}$ prices. We conclude in Section IV.

\section{An Event Study of the EU ETS}

The EU Emissions Trading System (ETS) was developed as one of the central mechanisms for which the European Union member states could achieve compliance with the commitments under the Kyoto Protocol and is in many ways a remarkable accomplishment. The world's first significant cap-and-trade system for $\mathrm{CO}_{2}$, the ETS covers most industries and 27 countries, including several that took on no Kyoto obligations. The ETS did not cover emissions from transportation fuels or residential fuel combustion. The ETS has been rolled out in phases. The first phase, running from 2005 through 2007, was intended as much to develop institutions and gain regulatory experience as to achieve substantial $\mathrm{CO}_{2}$ reductions. The overall cap for the market was an aggregation of caps developed by each participating country through their "national allocation plans," previously analyzed by Betz, Eichhammer, and Schleich (2004). The EU established guidelines for the development of these plans, but member states were left with significant latitude. Efforts at setting an appropriate cap were complicated by the fact that, prior to 2005, the monitoring of 
$\mathrm{CO}_{2}$ emissions of many facilities and countries was unreliable at best. Caps were supposed to be set in a manner that would place emissions reductions on a trajectory consistent with meeting the Kyoto targets. However, the effective stringency of the Kyoto targets varied greatly among EU member states. The implementation plans reflected large differences between member states in the level of total $\mathrm{CO}_{2}$ reductions and how many reductions would come from industries covered by the ETS.

One source of variation among participating nations was their relative approach to assigning permits to the covered industries. As chronicled in Ellerman and Buchner (2008), Kettner et al. (2008), and Ellerman and Joskow (2008), countries such as Spain, Italy, and the United Kingdom appear to have imposed more stringent caps. As a consequence, the affected industries in these countries, particularly in the power sector, were allocated fewer permits than their observed emissions. These firms were therefore net buyers of permits within the EU. Industries in other countries, particularly in Eastern Europe, were observed to emit far less than their allocations.

Another important contrast lay in the allocation of permits across the various industrial sectors. Online Appendix Table A1 shows the allocations relative to emissions by industrial sector of firms we have matched. In general, many regulated firms in the manufacturing sectors received more permits than they subsequently needed to cover their observed emissions. Those providing power and heat, predominantly electricity firms, were generally "short" of permits, but still received allocations equivalent to a substantial majority of their emissions.

Overall, by the end of phase I, available permits exceeded measured emissions by about 2.8 percent (Convery, Ellerman, and De Perthuis 2008). Although the eventual surplus in permits led to a perception of intentionally lax regulation through "overallocation," the picture is more nuanced. An ex post realization of a surplus does not necessarily imply over-allocation, since a surplus of allowances can arise from either over-allocation or over-abatement. Since emissions prices were quite high for some of this period, it is natural to expect some abatement to have occurred, at least while emission prices were high. Studies by Ellerman and Buchner (2008) as well as Delarue, Voorspools, and D'haeseleer (2008) indicate that at least some abatement did take place. In addition, macroeconomic and weather shocks may have played a role in lower than expected emissions, and specific directed regulations such as aggressive subsidies for renewable electricity production may have been sufficient to tip the market into surplus (Convery, Ellerman, and De Perthuis 2008). Importantly, none of this was known for much of the first phase, and it was only after the phase was more than two-thirds complete that the surplus conditions pushed emissions prices to near zero.

\section{A. ETS Market Performance}

The most notorious aspect of the ETS during phase I was the volatility of the permit prices, which was greatly exacerbated by the fact that permits could not be "banked" for use beyond 2007. The ETS market was characterized by an early period in which prices were higher than anticipated, and a later period in which the price eventually reached zero in the face of a surplus of permits that held no value beyond 2007. From the onset of trading in January 2005 through March 2006, prices rose steadily to over $€ 30$ per tonne. While in hindsight this price rise appears 
somewhat surprising given the eventual surplus of permits, it was not necessarily considered anomalous at the time. Many attribute the relatively high prices during this phase to the fact that prices for natural gas, which largely defines the marginal costs of reducing $\mathrm{CO}_{2}$ emissions in the power sector through its substitution for coal, were steadily rising during this period. ${ }^{3}$ In addition, while firms from countries "short" on permits were apparently relatively active in trading from the beginning, those from many "long" Eastern European countries were not active due to delays in integrating their regulatory platforms with that of the EU. This may have contributed to masking what later emerged as a surplus of available permits.

The lack of reliable information about aggregate emissions was also a critical contributor to the volatility in prices. This was highlighted on April 25, 2006, when the first reports of country-level emissions began to leak into the permit market. As can be seen in Figure 1, the reaction was dramatic. Over the next few days, the permit price as reported on the European Climate Exchange fell from $€ 28$ (per tonne) on April 25 to $€ 14$ on April 28 . The price drop hit both phase I (2005-2007 compliance period) permit prices as well as permits covering phase II (2008-2012 compliance period), which had begun trading in 2006. These initial reports were revised shortly after they were leaked to the public, and information from other countries was released in the following days. By May 15, when the final emissions totals were officially released, phase I prices had rebounded and then fallen slightly again to settle around $€ 16$.

During this one month period, the general movements of prices for both the phase I and phase II permits had been generally consistent with each other, although the magnitudes were more muted in the case of the longer term phase II permits. Later in 2006 the two price series diverged for good, with the phase I prices starting a steady decline toward zero and the phase II series settling into a range around $€ 20$.

\section{B. Equity Market Effects}

We now turn to the question of how the sharp devaluation in permit prices in April 2006 impacted expectations about firm profitability. A few papers have empirically looked at different segments of the EU market. Sijm, Neuhoff, and Chen (2006) examine the implications specifically for electricity prices in the Netherlands and Germany and find substantial pass-through of carbon cost. Convery, Ellerman, and De Perthuis (2008) note that net incomes of several large electricity producers increased throughout phase I of the ETS. Two similar papers, Veith, Werner, and Zimmermann (2009), and Oberndorfer (2009) examine stock market returns of electricity companies using a panel regression of share prices on $\mathrm{CO}_{2}$ prices throughout the phase I period. Both find that share prices of large electricity producers who were regulated under the ETS were positively linked with prices for $\mathrm{CO}_{2}$. However, in contrast to our results, Veith, Werner, and Zimmermann (2009) find that share prices of "clean" electricity producers not covered under the ETS had no significant response to $\mathrm{CO}_{2}$ prices. 

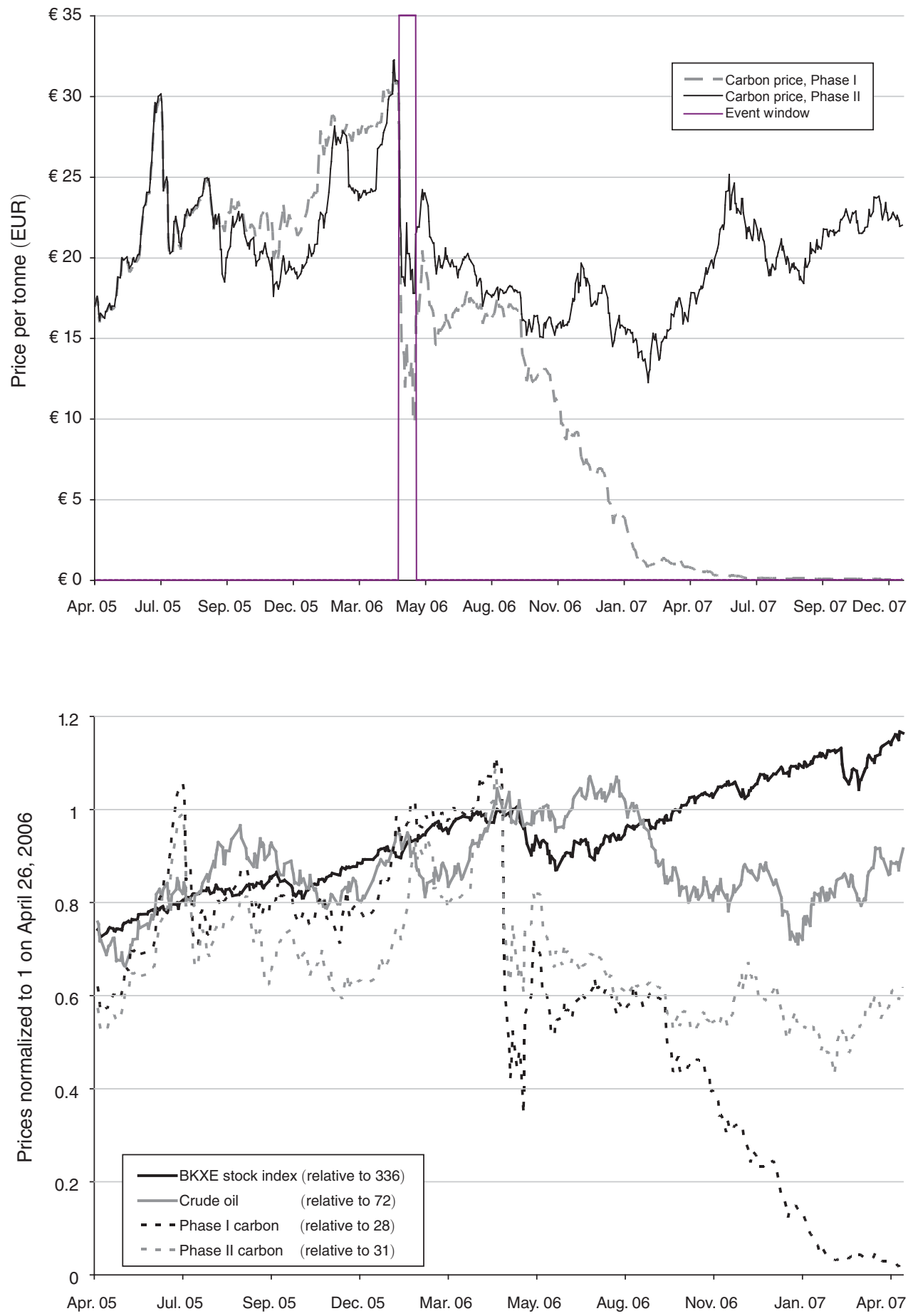

Figure 1. EU Carbon Prices, Stock Index, and Oil Prices 
While these latter two papers also study equity market impacts of ETS prices, our work differs in several important ways. First, we choose to focus on the specific three-day event of the price crash in an attempt to isolate the most dramatic ETS price change from other movements in the ETS price that could be either potentially endogenous or correlated to other market drivers such as macroeconomic or commodity price shocks. Second, we examine a broad set of industries that were both directly and indirectly impacted by ETS regulations. Third, in Section III, we decompose the impact by looking at industrial and firm characteristics.

In this paper, we also utilize equity prices of publicly traded firms. It is important to note that many firms directly subject to the $\mathrm{CO}_{2}$ cap, as well as those in impacted industries, are privately held or government owned. A large number of publicly traded firms were also affected, however, and we focus our attention on these firms. We employ a standard event-study approach. ${ }^{4}$ We examine firms contained in the Dow Jones STOXX 600 index, which is similar to the S\&P 500 but covers European firms..$^{5}$ We focus on the three days after the initial leak of permit market information, the daily returns for April 26-28. Several papers have utilized an event study approach to assess the impact of environmental regulation on firm profits. ${ }^{6}$ Because this approach has usually utilized a political or legal decision as the "event," a common concern has been that information may have leaked into the market before the examined event date. Here we can be confident that there was little leakage of information as this information would have impacted the $\mathrm{CO}_{2}$ price, which was steadily rising up until our event date.

A related concern in this context is that the price of allowances themselves may be driven by shocks to the product markets of the firms that are regulated. This is a central reason why we focus our analysis on this rather unique event. The price shock here is driven by the update of information about aggregate amounts of allowances consumed, and can therefore be considered an environmental cost shock that is exogenous to the underlying product markets of firms. By contrast, previous work on the EU carbon market, which utilizes full panel data, is much more vulnerable to the endogeneity criticism.

We utilize the following specification for investigating the potential for abnormal returns during this event window. For firm $i$, industry $j$, and day $t$ :

$$
S_{i j t}=\alpha_{i}+\beta_{i} M_{t}+\gamma_{j} E V E N T_{t}+\epsilon_{i j t}
$$

where $S_{i j t}$ is the firm's daily return (i.e., the percent change in the stock price), $M_{t}$ is the daily return of the Dow Jones STOXX 600 market index, and EVENT is a dummy variable that is scaled according to the length of the event window. 7

\footnotetext{
${ }^{4}$ This method is based on Fama et al. (1969). Notable surveys include Brown and Warner (1985), MacKinlay (1997), and Corrado (2011).

${ }^{5}$ We chose this index because of its breadth of firms and of geography. Other commonly cited European indices such as the FTSE 100 and the DAX are more limited in coverage of European countries and industries.

${ }^{6}$ These include Kahn and Knittel (2002) and Linn $(2006,2010)$. A related literature has examined environmental information disclosure and market returns (Dasgupta, Laplante, and Mamingi 2001; Dasgupta et al. 2006; Beatty and Shimshack 2010; Fisher-Vanden and Thorburn 2011).

${ }^{7}$ For our base specification, where the event window is three days, $E V E N T_{t}$ is set to be $1 / 3$ so that $\gamma_{j}$ represents the industry-average, cumulative excess return for industry $j$ during the three-day event window.
} 
We estimate $\gamma_{j}$ for each two-digit NACE industry classification. ${ }^{8}$ The window for estimating the relationship with the market index, $\beta_{i}$, is the two years overlapping the event window, April 2005-April 2007.

Table 1 reports the cumulative abnormal returns, $\gamma_{j}$, by industry. Many of the largest significant declines were in industries that feature prominently in the EU ETS: Basic Metals, Oil and Gas Extraction, and Utilities. However, there are also notable declines in such industries as Sewage and Refuse, Land Transportation, and Water Utilities. As we describe below, each of these industries are relatively large users of electricity and sell to relatively local markets. Conversely other industries such as chemicals and food manufacturing, which are also large electricity users but have sales that are not highly concentrated in the EU, experienced little change during the carbon price-reduction event.

One possible explanation is that share prices were responding to new information about the volatility of carbon prices, rather than the levels of carbon prices. We evaluate this possibility by running an event study on the market response to another window in which the ETS price experienced its largest three day gain before the collapse of April-May 2006. We posit that traders' expectations about the volatility of prices were similarly affected during this large increase in prices as they were by the main event when prices fell. This window was in January of 2006, when ETS prices rose by 16 percent. The last two columns of Table 1 describe the results for this "counterevent." The correlation between the point estimates in price-reduction event and those in the counter-event is -0.32 . If the volatility explanation were correct, we would expect that abnormal returns responding to a $\mathrm{CO}_{2}$ price increase to have the same sign as a price decrease. We describe in a later section that the volatility explanation is also inconsistent with the pattern of firm-level results for the electricity industry.

We report standard errors clustered by date in Tables 1 and 2 because of plausible contemporaneous correlation across firms on the same day. We explore the sensitivity of the significance of the results for the average across all industries and separate estimates for three major industries: crude petroleum extraction, basic metals, and electricity and gas. Online Appendix Table A2 reports the OLS coefficients and standard errors, robust standard errors, and standard errors clustered by firm, by two-digit NACE industry, by industry and date, and by date. We find that our preferred standard errors (clustered by date) are about twice as large as the robust standard errors. The last row of online Appendix Table A2 reports two-way clustered standard errors (by firm and date); this corrects standard errors in the event study which would otherwise be biased by serial correlation and correlated contemporaneous error terms across firms (Salinger 1992; Petersen 2009). For contemporaneous correlation, Salinger (1992) suggests creating a portfolio of returns for each industry. ${ }^{9}$ However, as we are

\footnotetext{
${ }^{8} \mathrm{NACE}$ is the European standard classification of productive economic activities. The US classification, NAICS is more widely used in the literature, but is more difficult to link to the characteristics of European firms and countries. A previous version of this paper utilized NAICS and found similar results. Weiner (2005) evaluates several industrial classification schemes and finds drawbacks in each.

${ }^{9}$ Salinger (1992) describes two methods for correcting standard errors. If an event study has long event windows that are not concurrent across firms, he recommends addressing serial correlation by using GLS (this is akin to clustering by firm). However, if the event windows are short and concurrent for a set of firms, he suggests using the Mandelker-Jaffe technique of collapsing the firms with the same event window to a single portfolio. Rather than collapsing data, we cluster by date and firm to address this issue.
} 
Table 1-Stock Market Three Business Day Cumulative Abnormal Returns by Industry

\begin{tabular}{|c|c|c|c|c|c|c|}
\hline \multirow{2}{*}{$\frac{\text { NACE }}{10}$} & \multirow{2}{*}{$\begin{array}{r}\text { Industry description } \\
\text { Coal and lignite mining }\end{array}$} & \multirow{2}{*}{$\frac{\text { Observations }}{2}$} & \multicolumn{2}{|c|}{$\begin{array}{l}-44 \% \text { permit price drop } \\
\text { April } 26,2006 \text { main event }\end{array}$} & \multicolumn{2}{|c|}{$\begin{array}{l}+16 \% \text { permit price rise } \\
\text { January } 13,2006 \text { event }\end{array}$} \\
\hline & & & -0.032 & $(0.021)$ & 0.045 & $(0.034)$ \\
\hline 11 & Crude petroleum extraction & 20 & -0.032 & $(0.017) *$ & 0.038 & $(0.017)^{* *}$ \\
\hline 27 & Basic metals & 15 & -0.031 & $(0.011)^{* * *}$ & 0.055 & $(0.027)^{* *}$ \\
\hline 90 & Sewage and refuse & 1 & -0.027 & $(0.012)^{* *}$ & 0.037 & $(0.033)$ \\
\hline 61 & Water transport & 2 & -0.027 & $(0.020)$ & 0.001 & $(0.023)$ \\
\hline 23 & Refining and coke & 2 & -0.027 & $(0.015) *$ & 0.037 & $(0.016)^{* *}$ \\
\hline 30 & Computer manufacturing & 2 & -0.023 & $(0.007) * * *$ & -0.056 & $(0.055)$ \\
\hline 13 & Metal ores mining & 7 & -0.023 & $(0.023)$ & 0.096 & $(0.034) * * *$ \\
\hline 16 & Tobacco manufacturing & 3 & -0.019 & $(0.005)^{* * *}$ & 0.019 & $(0.016)$ \\
\hline 40 & Electricity and gas & 26 & -0.017 & $(0.014)$ & 0.049 & $(0.026) *$ \\
\hline 70 & Real estate & 16 & -0.016 & $(0.003)^{* * *}$ & 0.023 & $(0.010)^{* *}$ \\
\hline 41 & Water & 4 & -0.016 & $(0.008) *$ & 0.035 & $(0.027)$ \\
\hline 60 & Land transport & 5 & -0.011 & $(0.010)$ & 0.004 & $(0.009)$ \\
\hline 25 & Rubber and plastics & 3 & -0.010 & $(0.010)$ & 0.006 & $(0.023)$ \\
\hline 72 & Computer activities & 11 & -0.009 & $(0.010)$ & 0.004 & $(0.005)$ \\
\hline 35 & Other transport & 8 & -0.009 & $(0.010)$ & 0.014 & $(0.010)$ \\
\hline 55 & Hotels and restaurants & 9 & -0.009 & $(0.004) * *$ & 0.025 & $(0.020)$ \\
\hline 34 & Motor vehicles & 11 & -0.008 & $(0.018)$ & -0.003 & $(0.007)$ \\
\hline 32 & Radio and TV & 12 & -0.008 & $(0.005)$ & 0.022 & $(0.029)$ \\
\hline 31 & Electrical machinery & 6 & -0.007 & $(0.014)$ & -0.002 & $(0.003)$ \\
\hline 52 & Retail trade & 19 & -0.006 & $(0.001)^{* * *}$ & 0.001 & $(0.012)$ \\
\hline 45 & Construction & 28 & -0.006 & $(0.004)$ & 0.007 & $(0.009)$ \\
\hline 33 & Medical instruments & 16 & -0.005 & $(0.006)$ & 0.009 & $(0.004)^{* *}$ \\
\hline 22 & Publishing and printing & 8 & -0.004 & $(0.006)$ & 0.002 & $(0.010)$ \\
\hline 62 & Air transport & 5 & -0.003 & $(0.003)$ & -0.016 & $(0.003)^{* * *}$ \\
\hline 21 & Pulp and paper & 5 & -0.003 & $(0.011)$ & 0.014 & $(0.009)$ \\
\hline 15 & Food manufacturing & 20 & -0.003 & $(0.005)$ & 0.004 & $(0.003)$ \\
\hline 74 & Other business activities & 56 & -0.001 & $(0.002)$ & 0.010 & $(0.002) * * *$ \\
\hline 67 & Auxiliary financials & 9 & 0.000 & $(0.003)$ & 0.047 & $(0.023)^{* *}$ \\
\hline 29 & Machinery & 18 & 0.000 & $(0.006)$ & 0.010 & $(0.008)$ \\
\hline 24 & Chemicals & 38 & 0.000 & $(0.002)$ & 0.007 & $(0.001)^{* * *}$ \\
\hline 65 & Financial intermediation & 53 & 0.001 & $(0.001)$ & 0.007 & $(0.002) * * *$ \\
\hline 18 & Apparel manufacturing & 5 & 0.002 & $(0.006)$ & -0.012 & $(0.006) * *$ \\
\hline 64 & Post and telecomm & 27 & 0.002 & $(0.001) * *$ & -0.014 & $(0.001)^{* * *}$ \\
\hline 36 & Furniture & 3 & 0.003 & $(0.004)$ & 0.032 & $(0.035)$ \\
\hline 66 & Insurance & 26 & 0.004 & $(0.008)$ & 0.002 & $(0.004)$ \\
\hline 92 & Recreational and cultural & 11 & 0.005 & $(0.010)$ & -0.008 & $(0.003)^{* * *}$ \\
\hline 85 & Health and social work & 1 & 0.007 & $(0.033)$ & 0.005 & $(0.010)$ \\
\hline 19 & Tanning leather & 1 & 0.007 & $(0.002)^{* * *}$ & 0.016 & $(0.016)$ \\
\hline 28 & Fabricated metals & 6 & 0.008 & $(0.008)$ & 0.005 & $(0.007)$ \\
\hline 26 & Nonmetallic manufacturing & 9 & 0.009 & $(0.015)$ & 0.025 & $(0.009)^{* * *}$ \\
\hline 51 & Wholesale trade & 7 & 0.010 & $(0.007)$ & 0.021 & $(0.006) * * *$ \\
\hline 63 & Supporting transport & 10 & 0.014 & $(0.003)^{* * *}$ & -0.003 & $(0.007)$ \\
\hline 14 & Other mining & 1 & 0.016 & $(0.029)$ & -0.002 & $(0.011)$ \\
\hline \multirow[t]{2}{*}{71} & Renting machinery & 1 & 0.022 & $(0.023)$ & 0.043 & $(0.027)$ \\
\hline & All industries & 548 & -0.005 & $(0.003) *$ & 0.013 & $(0.006)^{* *}$ \\
\hline
\end{tabular}

Notes: Standard errors, in parentheses, are clustered by date. There are 552 firms and 249,844 observations.

*** Significant at the 1 percent level.

** Significant at the 5 percent level.

* Significant at the 10 percent level.

interested in the across-firm and across-industry heterogeneity, online Appendix Table A3 reports the two-way clustered standard errors for all industries that control for contemporaneous correlation of error terms and serial correlation (Petersen 2009; Cameron, Gelbach, and Miller 2011). The industry-specific results corrected for these potential standard error biases are similar to the main results in Table 1. 
TAble 2-Robustness of Event Study

\begin{tabular}{|c|c|c|c|c|c|c|}
\hline Industry description & $\begin{array}{c}\text { 12-month } \\
\text { window } \\
(1)\end{array}$ & $\begin{array}{c}\text { 6-month } \\
\text { window } \\
(2)\end{array}$ & $\begin{array}{c}\text { Preevent } \\
\text { (3) }\end{array}$ & $\begin{array}{c}\text { Debt-equity } \\
(4)\end{array}$ & $\begin{array}{c}\text { No } \\
\text { betas } \\
(5)\end{array}$ & $\begin{array}{c}\text { Big } \\
\text { event } \\
(6) \\
\end{array}$ \\
\hline Coal and lignite mining & -0.032 & -0.030 & $-0.036^{*}$ & $-0.032 * * *$ & $-0.041 *$ & -0.078 \\
\hline Crude petroleum extraction & $-0.030^{*}$ & $-0.029 *$ & $-0.036^{* *}$ & -0.032 & $-0.044 *$ & -0.069 \\
\hline Basic metals & $-0.029 * *$ & $-0.030 * *$ & $-0.037 * * *$ & -0.031 & $-0.047 * * *$ & -0.026 \\
\hline Sewage and refuse & $-0.029 * *$ & $-0.029 * *$ & $-0.029 * *$ & -0.028 & $-0.033^{* * *} *$ & $-0.094 *$ \\
\hline Water transport & -0.027 & -0.021 & -0.025 & -0.027 & $-0.035^{* *}$ & $-0.128 * *$ \\
\hline Refining and coke & -0.024 & $-0.026^{*}$ & $-0.029 *$ & -0.027 & $-0.037 * *$ & -0.087 \\
\hline Computer manufacturing & $-0.022 * * *$ & $-0.021 * * *$ & $-0.024 * * *$ & -0.023 & $-0.034 * * *$ & $-0.081 *$ \\
\hline Metal ores mining & -0.023 & -0.021 & -0.031 & $-0.023^{*}$ & -0.041 & 0.016 \\
\hline Tobacco manufacturing & $-0.020 * * *$ & $-0.022^{* * *}$ & $-0.021 * * *$ & -0.020 & $-0.025^{* * *}$ & -0.018 \\
\hline Electricity and gas & -0.017 & -0.017 & -0.019 & -0.017 & -0.026 & -0.031 \\
\hline Real estate & $-0.017 * * *$ & $-0.016^{* * *}$ & $-0.019 * * *$ & -0.017 & $-0.025^{* * *}$ & -0.042 \\
\hline Water & $-0.017^{*}$ & $-0.016^{*}$ & $-0.017^{*}$ & -0.017 & $-0.023^{*}$ & -0.025 \\
\hline Land transport & -0.010 & -0.009 & -0.011 & $-0.012 * *$ & $-0.02 * * *$ & -0.033 \\
\hline Rubber and plastics & -0.009 & -0.005 & -0.011 & -0.011 & $-0.022 * *$ & $-0.087 * *$ \\
\hline Computer activities & -0.008 & -0.005 & -0.012 & -0.009 & -0.022 & -0.023 \\
\hline Other transport & -0.007 & -0.005 & -0.012 & -0.009 & -0.022 & -0.042 \\
\hline Hotels and restaurants & $-0.009 * *$ & $-0.008^{*}$ & $-0.008^{*}$ & $-0.009 * * *$ & -0.017 *** & -0.012 \\
\hline Motor vehicles & -0.007 & -0.007 & -0.008 & -0.009 & -0.020 & -0.023 \\
\hline Radio and TV & -0.005 & -0.004 & $-0.01 *$ & -0.008 & $-0.022 *$ & $-0.063 * *$ \\
\hline Electrical machinery & -0.007 & -0.005 & -0.019 & $-0.007 * * *$ & -0.021 & 0.017 \\
\hline Retail trade & $-0.007 * * *$ & $-0.007 * * *$ & $-0.006^{* * *}$ & -0.006 & $-0.014 * * *$ & 0.023 \\
\hline Construction & -0.005 & -0.003 & $-0.008 * *$ & $-0.006^{*}$ & $-0.018 * * *$ & -0.020 \\
\hline Medical instruments & -0.004 & -0 & -0 & -0.005 & -0 & -0.022 \\
\hline Publishing and printing & -0.004 & -0.002 & -0.005 & -0.002 & $-0.011^{* *}$ & $-0.036^{*}$ \\
\hline Air transport & -0.004 & -0.003 & -0.002 & -0.003 & $-0.014 * * *$ & -0.022 \\
\hline Pulp and paper & -0.004 & -0.003 & -0.007 & $-0.003^{* * *}$ & -0.013 & -0.045 \\
\hline Food manufacturing & -0.003 & -0.002 & -0.003 & -0.003 & -0.010 & -0.005 \\
\hline Other business activities & -0.001 & 0.000 & -0.003 & -0.002 & -0.012 & -0.018 \\
\hline Auxiliary financials & 0.000 & 0.0 & -0.004 & 0.000 & -0.013 & -0.023 \\
\hline Machinery & 0.001 & 0.002 & -0.005 & 0.000 & -0.014 & 0.002 \\
\hline Chemicals & 0.000 & 0.001 & -0.001 & $0.000^{*}$ & -0.010 & -0.010 \\
\hline Financial intermediation & 0.001 & 0.002 & -0.001 & $-0.002^{* *}$ & -0.009 & -0.006 \\
\hline Apparel manufacturing & 0.002 & 0.003 & 0.002 & $0.002^{* * *}$ & -0.008 & -0.022 \\
\hline Post and telecomm & $0.003^{*}$ & $0.003 *$ & $0.003 * *$ & $0.002^{* * *}$ & -0.006 & -0.011 \\
\hline Furniture & 0.005 & $0.006^{*}$ & 0.000 & 0.003 & -0.010 & -0.027 \\
\hline Insurance & 0.004 & 0.005 & 0.002 & 0.004 & -0.008 & -0.017 \\
\hline Recreational and cultural & 0.005 & 0.007 & 0.004 & $0.007 * *$ & -0.003 & 0.004 \\
\hline Health and social work & 0.010 & 0.014 & 0.004 & 0.007 & -0.002 & 0.018 \\
\hline Tanning leather & $0.010 * * *$ & $0.013 *$ & $0.006^{*}$ & 0.007 & -0.002 & -0.006 \\
\hline Fabricated metals & 0.009 & 0.010 & 0.005 & $0.008^{* * *}$ & -0.004 & -0.043 \\
\hline Nonmetallic manufacturing & 0.010 & 0.012 & 0.005 & 0.009 & -0.001 & -0.023 \\
\hline Wholesale trade & 0.010 & 0.012 & 0.007 & 0.010 & 0.000 & 0.004 \\
\hline Supporting transport & $0.014 * * *$ & $0.017^{*}:$ & $0.012 * * *$ & 0.014 & 0.004 & 0.038 \\
\hline Other mining & 0.017 & 0.021 & 0.014 & 0.016 & 0.006 & 0.024 \\
\hline Renting machinery & 0.025 & 0.029 & 0.020 & $0.021 * * *$ & 0.009 & $-0.115^{* *}$ \\
\hline All industries & $-0.005^{*}$ & -0.003 & -0.006 & $-0.006^{* *}$ & $-0.016^{*}$ & -0.019 \\
\hline
\end{tabular}

Notes: Industries are sorted by main event in Table 1 . See Table 1 for other notes.

Table 2 reports several specification robustness checks drawing on the event study literature. ${ }^{10}$ We put in controls for the impact of financial leverage in stocks,

${ }^{10}$ We follow event study methods used in recent papers. See Corrado (2011) for a review of this literature. Much of this literature has focused on standard error corrections to the typical two-step estimator in finance, whereby one first estimates the abnormal returns and second uses these returns as a dependent variable. See Linn (2010) for a recent application of this method. We have also used this procedure (see Bushnell, Chong, and Mansur 2009). 
consider the possibility of event-induced changes in volatility, and vary the length of the event window. Columns 1 and 2 summarize the results using shorter windows of one year and six months, respectively. Column 3 utilizes only pre-event data to estimate $\alpha_{i}$ and $\beta_{i}$. Column 4 controls for a firm's debt-to-equity ratio during the event window. Note that the net present value of all future profits equals the sum of equity and debt. By including the debt-equity ratio, we are testing the robustness of our results that the findings represent changes in profits, not just in equity. Column 5 provides the results using just the raw returns with no controls for the market index (i.e., no $\beta_{i}$ ). Column 6 examines the question of the appropriate time window for the event. From Figure 1, we see that the volatility in permit prices continued beyond the three-day window examined above. Here we examine a 30-day event window consisting of five days prior and 25 days after April 25, 2006. In each case, the qualitative results are robust. For each of the first five columns, the correlation between the industry estimates here and those in the main results of Table 1 exceeds 0.98 . For the longer event in column 6, the market experienced a more significant decline overall and the correlation with the main results of Table 1 is less, 0.47 .

These results summarize general effects but do not account for firm heterogeneity within each classification. In the following sections we provide some structure to the analysis by describing the theory of how input cost shocks, such as the ETS price drop, influence firm profits.

\section{Emissions Regulations and Firm Profits}

Having established that the carbon price-crash impacted sectors differentially, and that "dirtier" sectors appear to have performed the worst during the event, we turn to a deeper examination of the economic mechanisms that produced this result. We briefly discuss a theoretical model considering the potential impacts of environmental regulation, or more specifically emissions costs, on firm profitability and performance. The model provides a useful framework for decomposing and illustrating the various potential impacts, both positive and negative, of emissions costs on firms. In the following sections, we then present empirical tests of which market elements and firm characteristics most influenced market performance during this period.

Consider firm $i$ producing for a market represented by the demand curve, $P\left(q_{i}+q \neq i\right)$, where $q_{\neq i}$ represents total production by other firms in this market. The firm is subject to cap-and-trade regulation of its emissions, which are in turn a function of its emissions rate, $r_{i}$, its total production, $q_{i}$, and level of abatement, $I_{i} \cdot{ }^{11}$ We assume that the production technology, along with a given level of abatement, $I_{i}$, determines the emissions rate, $r_{i}\left(q_{i}, I_{i}\right)$, and that abatement incurs costs of $k\left(I_{i}\right)$. The per-unit price of emissions allowances is $\tau$, resulting in direct compliance costs of

\footnotetext{
However, following a referee's recommendation, we now use a single-step procedure common in the economic literature that addresses heteroskedasticity and correlation across stocks through clustered standard errors.

${ }^{11}$ The model is intended to be general, encompassing both perfectly competitive industries and those in which individual firms have market power. However, it is important to also acknowledge aspects of oligopoly competition that are not explicitly represented within this framework. In oligopoly settings, cost shocks such as environmental regulations can increase profitability by increasing the severity of market power in an industry. In a dynamic setting, the environmental regulation could serve as a barrier to entry or even as a collusive focal point. Even in a static setting, the imposition of an environmental tax can increase margins under certain demand structures (Seade 1985).
} 
$\tau r_{i}\left(q_{i}, I_{i}\right) q_{i}$. However, the firm may possess allowances $A_{i}$ equal to its initial allocation less net sales. Considering both input and environmental costs, the profits of firm $i$ can be represented as

$$
\pi_{i}=P\left(q_{i}+q_{\neq i}\right) q_{i}-C_{i}\left(q_{i}, \omega\right)+\tau A_{i}-\tau r_{i}\left(q_{i}, I_{i}\right) q_{i}-k\left(I_{i}\right),
$$

where the function $C_{i}\left(q_{i}, \omega\right)$ represents the total cost of producing $q_{i}$ with a vector of input costs, $w$.

In the Appendix, we derive the following expression for how an exogenous shock to permit prices affect the profits of firm $i$ :

$$
\frac{d \pi_{i}^{*}}{d \tau}=P^{\prime} \frac{\partial q_{\neq i}^{*}}{\partial \tau} q_{i}^{*}+\left[P^{\prime} \frac{\partial q_{\neq i}^{*}}{\partial \omega} q_{i}^{*}-\frac{\partial C}{\partial \omega}\right] \frac{\partial \omega}{\partial \tau}+\left[A_{i}-r_{i} q_{i}^{*}\right]
$$

where $q_{i}^{*}$ and $\pi_{i}^{*}$ are consistent with profit maximization.

The individual terms in equation (3) illustrate the competing potential effects of a change in the allowance price. First, revenues may increase due to the fact that other firms in the industry have collectively responded by reducing output in direct response to the permit price. This is similar to a "raising rivals' costs" effect. ${ }^{12}$ Under the assumption that firms would reduce output in the face of an increase in allowance costs, this term would be positive. Second, the middle term on the right hand side of (3) captures the impact of changes in profits from the indirect effect of permits through input costs. Environmental regulations may increase the price of inputs like electricity that, in turn, affect the costs of downstream firms and therefore prices in the product market. This effect is theoretically ambiguous. We can think of these first two components as the (net) "revenue effect," or in other words, the passthrough of the cost of allowances on to product prices.

Third, the last term reflects the effect on direct compliance costs of changes in allowance prices. If a firm is a large emitter and has a low allocation of allowances, it will have high cost exposure to allowance prices. Conversely, if a firm is holding more allowances than it expects to consume in its own production, its value will be enhanced by higher allowance prices: i.e., the firm is "short" in allowances, $A<r q$.

For each firm, the magnitude of these effects will depend upon several factors: (i) whether the firm produces in a market that is subject to the environmental regulation (either directly or indirectly through input prices); (ii) the price elasticity of demand in that product market; (iii) how many permits the firm owns, and (iv) the convexity of costs with respect to allowance prices in an industry. Figure 2 helps to illustrate these factors for a given competitive, product market. We assume that the firms in this market face demand curve $D$, and have a supply function reflecting marginal costs $c_{\tau 1}$ before the imposition, or increase, in allowance prices. Demand is assumed to be unaffected by a change in allowance prices.

The classic analysis of the incidence of taxation implies a vertical shift of the marginal cost curve to $c_{\tau 2}$. In the context of environmental regulation, this is

\footnotetext{
${ }^{12}$ Salop and Scheffman (1983).
} 

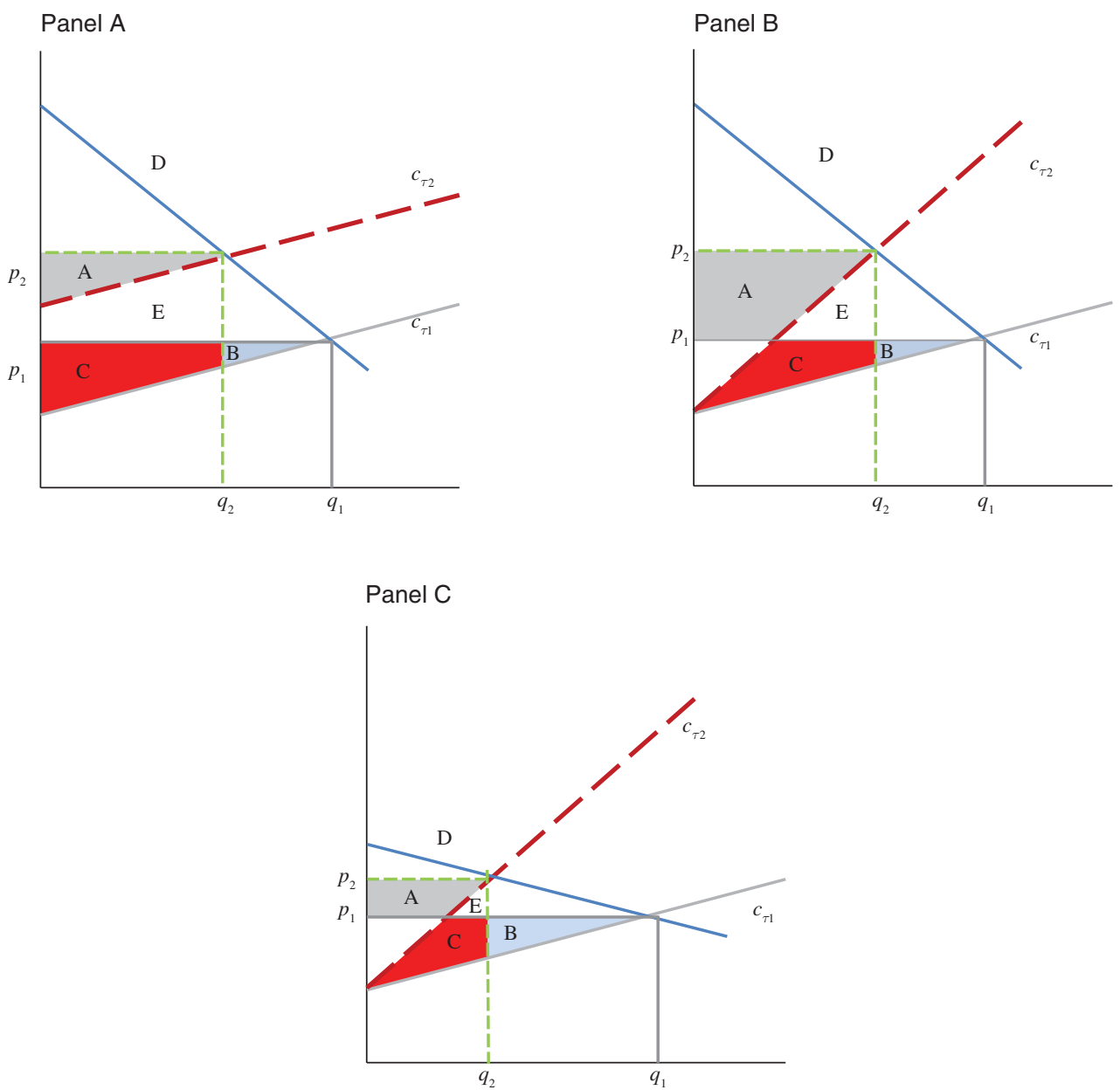

Figure 2. Theoretical Change in Producer Surplus under Environmental Regulation

Notes: Under a tax, or auctioned permits, firms gain area A but lose areas B and C. However, if firms are allocated permits equal to their equilibrium emissions, they gain $\mathrm{A}$ and $\mathrm{D}$ and lose only $\mathrm{B}$.

equivalent to assuming that emissions rates are constant for all quantities produced. In this case, the producer surplus is reduced from the sum of areas B and $\mathrm{C}$ to the area $\mathrm{A}$ in Figure 2, panel A. The allocation of permits or emissions tax revenues would then be critical in determining the net effect of the regulation. If firms in this market received a free allocation equivalent to 100 percent of their ex post emissions, this would be a transfer equivalent to the areas $\mathrm{C}$ and $\mathrm{D}$, which totally offset the increased regulatory cost. As long as the demand for the product is sufficiently inelastic (i.e., as long as the new equilibrium market quantity is at least the monopoly solution without the regulation), profits will improve because revenue (less production costs) will increase more than the increase in environmental costs. Indeed as Bovenberg and Goulder (2001) demonstrate, only a relatively small allocation of emissions allowances is necessary to fully compensate many industries for changes in profits due to $\mathrm{CO}_{2}$ costs. 
Even without an allocation of allowances, the impact on firm profits can be ambiguous. This is due to the fact that there are both heterogeneous firms and production technologies within most markets. Consider a case where emissions rates are increasing with production quantities, as illustrated in Figure 2, panel B. The increase in allowance costs now rotates marginal costs, and therefore increases prices in this perfectly competitive circumstance. The increase in average costs is well below the increase in marginal costs, however. Now the new producer surplus, area A, could be larger than the previous surplus of B and C. A similar effect could arise if an individual firm has technology with a lower emissions rate than its rivals. Again, product prices could rise faster than the firm's average production costs.

The magnitude of the revenue effect depends upon consumers' burden for the allowance price: If most of the incidence of an increase in emissions costs is passed on to consumers, firms can profit from more stringent regulation. In contrast, if a firm sells in a market with a high demand elasticity, then even a substantial convexity in the marginal cost curve would not compensate for the fact that the producer is absorbing the bulk of the incidence (Figure 2, panel C).

This discussion is meant to illustrate the varied potential effects and emphasize the importance of several key industry characteristics in determining the net effects of environmental regulations. In the following sections, we develop several proxy variables meant to reflect these characteristics in order to examine the market return of individual firms and industries in response to a substantial decline in emissions costs.

\section{Testing Determinants of Profitability}

In the following subsections, we examine industry and firm characteristics that determine the relative impact of $\mathrm{CO}_{2}$ price changes on profitability. Profitability drivers include cost exposure to the emissions market through one's emissions relative to one's allowance holdings, as well as potential revenue effects driven by cost impacts on competitors within an industry.

We begin with a focus on the electricity industry for several reasons. First, this sector was by far the largest single source of emissions, accounting for 57 percent of covered emissions during this phase of the market (Kettner et al. 2008). Second, as described above, allocations to this sector were relatively conservative. Most firms in this sector were expected to be net short, and therefore "buyers" on the allowance market. Third, this industry offers more detailed firm-level data than the manufacturing sector, allowing us to examine firm-level characteristics.

\section{A. Electricity Industry Impacts}

The ETS price can impact firm profits through the direct cost effect of the regulation, as well as the impact on the prices of the products sold by the regulated firms. As the electricity sector is the largest and most carbon-intensive sector, these effects are expected to dominate. To the extent that industry prices rise faster than the costs of a specific firm, that firm can benefit from the regulation.

One notable market impact of the ETS price crash is the interaction with wholesale electricity prices. Figure 3 illustrates the clearing prices of several electricity 


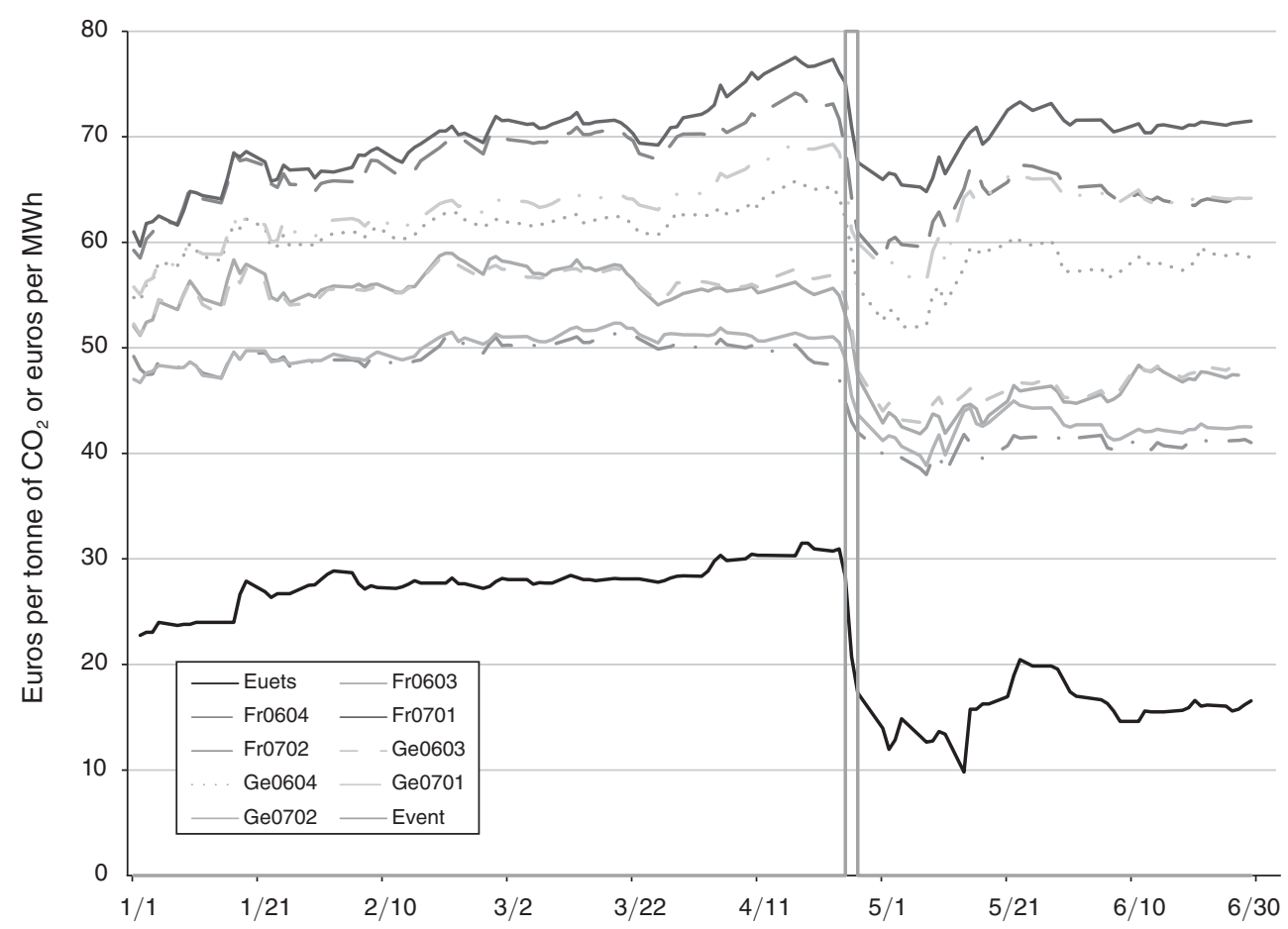

Figure 3. French and German Contracts for Quarterly Baseload Electricity (e.g., fr0603 is French Quarter 3, 2006)

futures contracts traded on the European Energy Exchange. The figure plots the daily clearing prices of contracts for "baseload," or all-hour, electricity delivered to the German and to the French grids during the last two quarters of 2006 and the first two quarters of 2007. ${ }^{13}$ While there is seasonality in the overall levels of these clearing prices, all clearly and immediately respond the EU ETS price change. These continental European electricity prices for both near term and longer term deliveries all fell by about 10 percent between April 25 and May 3, 2006. As we discuss below, our results indicate that equity market reaction in general seemed to be focused on the impacts of ETS prices on revenues rather than costs in this and other sectors.

Equation (3) illustrates that this impact would not be felt uniformly by firms within the industry. Although indirect costs are not a significant issue in the electricity industry, we can decompose the firm-level effects by considering their revenues and direct cost exposure. To measure direct cost exposure we utilize the emissions and allowance data contained in the EU's Community Independent Transaction Log (CITL) and from CARMA. ${ }^{14}$

\footnotetext{
${ }^{13}$ The source of these data is the European Energy Exchange. See: www.eex.com.

${ }^{14}$ This CITL dataset contains facility level information on the allocation and emissions of over 12,000 facilities throughout the EU. Unfortunately, firm ownership of facilities is reported inconsistently within the CITL, making necessary a manual matching of facilities to firms, and then to individual stock listings. The CARMA data is of power plant generation and emissions and comes from the Carbon Monitoring for Action project (carma.org) published by the Center for Global Development, Washington, DC.
} 


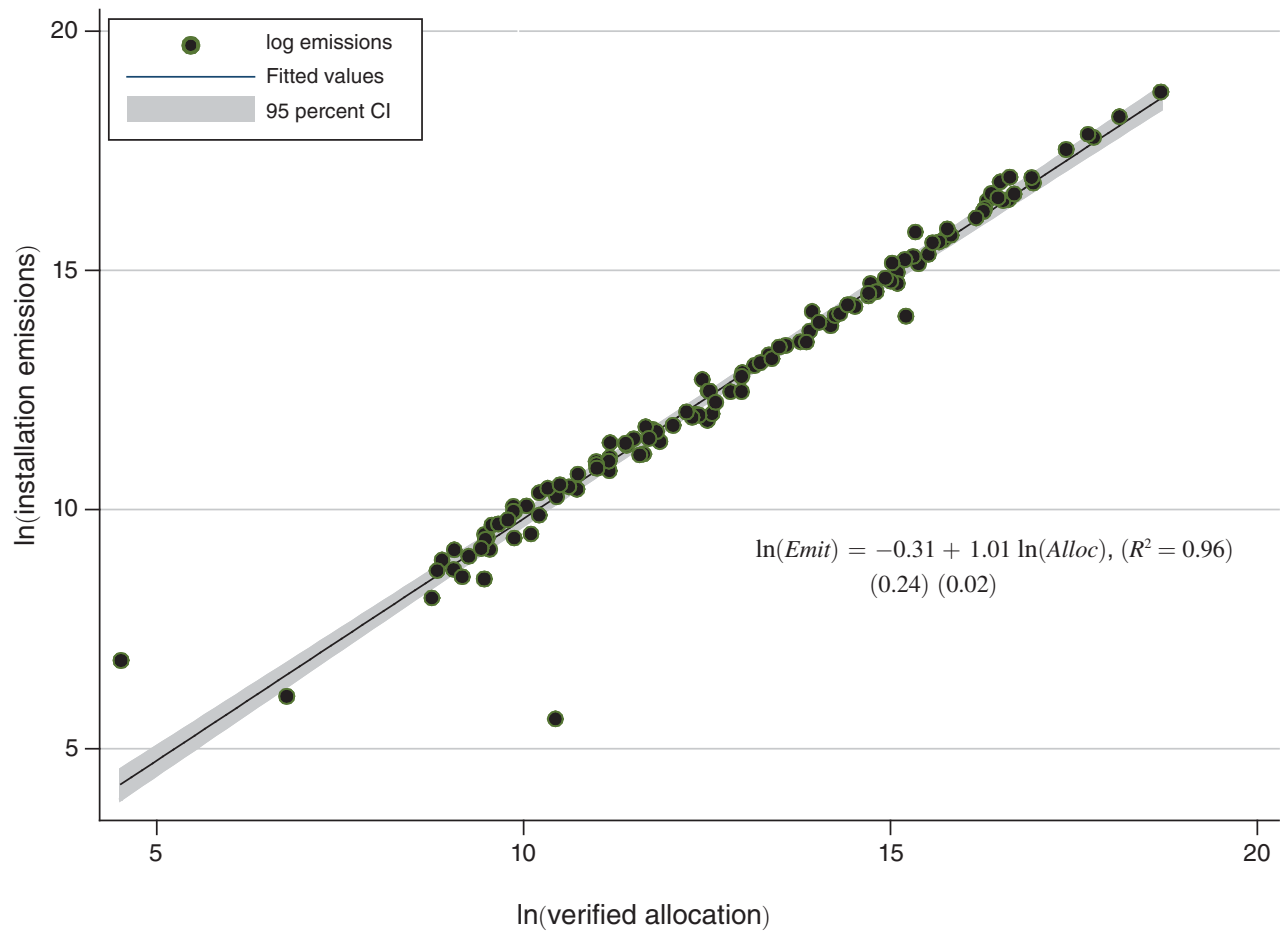

Figure 4. Most Firms' Allowances Similar to Emissions

(Current subsample of 124 firms with emissions linked to stock market data)

We were able to match emissions and allocations for facilities owned by 124 firms in our sample, including 15 in the electricity sector. ${ }^{15}$ For each of these firms, we take total 2005 emissions and permit allocations aggregated over all covered facilities owned by the firms. Using these data, we can construct a measure of $A_{i}$ using the historic 2005 allocation, and of $E_{i}$, the historic 2005 emissions (as measured in the spring of 2006). Note that, although the CITL registers all transactions, only the allocations and emissions data are currently publicly available. Therefore, we do not know the actual holdings of a given firm on any day, only their initial allocations. Our values for $\left(A_{i}-E_{i}\right)$ should be considered only as a proxy for firms' actual net positions at the time of the price-crash. Importantly, the broader market also did not know these positions and was relying upon the same data.

As described above, many industry classifications were "long" in permits during this period. The important exception is the power industry which as a whole was net short of permits (Ellerman and Buchner 2008). Given the lack of market information about permit trading, investors were unlikely to know the exact net position of firms, and may have had difficulty even estimating the sign of net position. Figure 4

\footnotetext{
${ }^{15}$ Matching occurred in two stages. In one stage, primary internet domain names for firms (SP500 and STOXX600) were gathered from the ORBIS database and these were matched to the internet domain names taken from the CITL records of e-mail addresses. In the second stage, facilities were matched by hand through internet searches on the largest emitting facilities and firms drawn from the largest emitting sectors.
} 
Table 3-Stock Market Cumulative Abnormal Returns for Firms in the Electricity Sector

\begin{tabular}{|c|c|c|c|c|c|c|c|c|}
\hline \multirow{2}{*}{$\begin{array}{l}\text { Stock name } \\
\text { Fortum }\end{array}$} & \multicolumn{2}{|c|}{$\begin{array}{c}\text { Main } \\
\text { event } \\
(1)\end{array}$} & \multicolumn{2}{|c|}{$\begin{array}{c}\text { January } \\
\text { counter event } \\
(2) \\
\end{array}$} & \multirow{2}{*}{$\begin{array}{c}\text { Carbon } \\
\text { per MWh } \\
(3) \\
0.214\end{array}$} & \multirow{2}{*}{$\begin{array}{c}\begin{array}{c}\text { Carbon } \\
\text { per equity } \\
(4)\end{array} \\
142.8\end{array}$} & \multirow{2}{*}{$\begin{array}{c}\begin{array}{c}\text { Allowances } \\
\text { per equity } \\
(5)\end{array} \\
157.1\end{array}$} & \multirow{2}{*}{$\begin{array}{c}\begin{array}{c}\text { Net allowances } \\
\text { per equity } \\
(6)\end{array} \\
14.3\end{array}$} \\
\hline & -0.088 & $(0.075)$ & 0.086 & $(0.060)$ & & & & \\
\hline Verbundgesellschaft & -0.086 & $(0.061)$ & 0.099 & $(0.063)$ & 0.252 & 610.5 & 535.5 & -75.0 \\
\hline British Energy Group & $-0.071 *$ & $(0.043)$ & $0.076 * *$ & $(0.032)$ & 0.108 & 1236.2 & 779.2 & -457.0 \\
\hline EDF & $-0.050 *$ & $(0.028)$ & $0.093 * *$ & $(0.044)$ & 0.104 & 459.1 & 402.6 & -56.4 \\
\hline RWE (XET) & $-0.045 * *$ & $(0.023)$ & 0.054 & $(0.052)$ & 0.909 & 3587.1 & 3436.8 & -150.3 \\
\hline Vestas Wind & -0.026 & $(0.033)$ & $0.086^{*}$ & $(0.049)$ & & & & \\
\hline $\mathrm{A} 2 \mathrm{~A}$ & $-0.024 * * *$ & $(0.004)$ & $0.066 * *$ & $(0.027)$ & 0.287 & 812.1 & 1029.8 & 217.8 \\
\hline Atel Holding ' $\mathrm{R}$ ' & -0.022 & $(0.015)$ & $0.046 *$ & $(0.025)$ & 718.1 & 821.6 & & \\
\hline DRAX Group & -0.019 & $(0.047)$ & $0.110 * * *$ & $(0.012)$ & 1.046 & 4384.0 & 3071.8 & -1312.2 \\
\hline United Utilities Group & $-0.018 * * *$ & $(0.005)$ & $0.030 *$ & $(0.016)$ & 0.1 & 0.1 & & \\
\hline EDP Energias de Portugal & -0.015 & $(0.011)$ & -0.018 & $(0.025)$ & 0.712 & 1283.8 & 1221.2 & -62.6 \\
\hline Solarworld & -0.013 & $(0.024)$ & $0.077 * * *$ & $(0.026)$ & & & & \\
\hline International Power & $-0.012 * *$ & $(0.005)$ & 0.091 & $(0.067)$ & 0.611 & 1203.1 & 1098.4 & -104.7 \\
\hline E.ON & -0.007 & $(0.015)$ & 0.003 & $(0.028)$ & 0.525 & 1196.0 & 1090.8 & -105.2 \\
\hline Red Electrica de Espana & -0.005 & $(0.012)$ & $0.055 *$ & $(0.03)$ & & & & \\
\hline Scot. \& Southern Energy & -0.004 & $(0.010)$ & $0.045^{*}$ & $(0.027)$ & 0.819 & 1626.7 & 1178.7 & -447.9 \\
\hline ENEL & -0.003 & $(0.006)$ & 0.037 & $(0.037)$ & 0.501 & 1320.2 & 1133.3 & -186.8 \\
\hline National Grid & -0.001 & $(0.007)$ & 0.022 & $(0.040)$ & & & & \\
\hline Terna & -0.001 & $(0.010)$ & 0.021 & $(0.037)$ & & & & \\
\hline Sofina & -0.006 & $(0.013)$ & $0.026^{*}$ & $(0.016)$ & & & & \\
\hline Union Fenosa & 0.004 & $(0.005)$ & 0.024 & $(0.015)$ & 0.972 & 1740.3 & 1382.7 & -357.6 \\
\hline Schneider Electric & 0.011 & $(0.020)$ & 0.003 & $(0.013)$ & & & & \\
\hline Iberdrola & $0.015 * * *$ & $(0.002)$ & 0.010 & $(0.013)$ & 0.349 & 608.2 & 529.7 & -78.6 \\
\hline Public Power & $0.052 * * *$ & $(0.012)$ & 0.014 & $(0.010)$ & 0.982 & 11659.6 & 11550.4 & -109.2 \\
\hline Coefficient estimates & & & & & $\begin{array}{l}0.071 \text { ** } \\
(0.033)\end{array}$ & $\begin{array}{l}7.445^{* * *} \\
(1.924)\end{array}$ & $\begin{array}{l}7.175 \text { *** } \\
(2.098)\end{array}$ & $\begin{array}{l}-5.937 \\
(31.510)\end{array}$ \\
\hline
\end{tabular}

Note: Standard errors, in parentheses, are clustered by date.

plots the 124 firms' permit allocations and emissions during 2005 and demonstrates this point. Many firms had been allocated permits that were very highly correlated with their 2005 emissions levels. We find that the log of initial allocation explains over 95 percent of the variation in the $\log$ of 2005 emissions. Similar effects are found when limiting the sample to the electricity sector.

Table 3 summarizes market effects for firms contained in the electricity sector. For each firm, columns 1 and 2 present the main April event and "counter-event" effects. The correlation between them is -0.65 . This suggests that the direction of the change in permit prices matters, and the impact is not driven by an increase in volatility. Columns 3-6 provide firm-level characteristics for the electricity firms. Several patterns emerge between the main price-reduction event coefficients and these firm characteristics. The biggest declines during the April event were concentrated within firms who produce electricity with relatively low $\mathrm{CO}_{2}$ emissions, such as the hydro- or nuclear-intensive firms Fortum, British Energy, and Electricite de France. Some coal-intensive firms such as Drax and RWE registered declines, but they were more modest than those of the "clean" producers. Lastly, network operators such as National Grid and Red Electrica, with no position in the production or sale of electricity, registered almost no impact.

To test these relationships, we limit the sample to the electricity sector and regress daily returns on firm fixed effects, firm-specific market returns, the average event effect $\left(E V E N T_{t}\right)$, and several measures of firm-level intensity (interacted with $\left.E V E N T_{t}\right)$ :

$$
S_{i j t}=\alpha_{i}+\beta_{i} M_{t}+\gamma \text { EVENT }_{t}+\eta \operatorname{INTENSITY}_{i} \times \text { EVENT }_{t}+\epsilon_{i j t},
$$


where the alternative measures of INTENSITY ${ }_{i}$ are represented, by carbon/MWh (column 3), carbon/equity (column 4), allowances/equity (column 5), and net permit position (column 6). The results of this regression are reported in the bottom row of Table 3. As with the previous results, we cluster the standard errors by date. ${ }^{16}$

The carbon intensity of the firm, both in terms of $\mathrm{CO}_{2}$ per $\mathrm{MWh}$ and $\mathrm{CO}_{2}$ per market cap, have significantly positive effects on abnormal returns during the April price-reduction event, indicating again that dirtier electricity firms fared better than cleaner ones during this event. These results are consistent with an explanation of the effects that emphasizes the importance of revenue impacts in the product markets. All the firms in Table 3 who sell bulk electricity experienced declines in revenues, and only some experienced significant declines in production costs.

Many of these firms were also substantial holders of emissions permits at the time of the crash in permit prices. However, the results with respect to net allowances are much less clear. The results for allowances are virtually identical for those for emissions, while there is no apparent relationship between net permit position and market performance. Recall from Figure 4 that emissions and allocations are highly colinear, and that the true net position was not known by the market during these events. One explanation, therefore, is that the relationship between abnormal returns and allowances is essentially a proxy for the relationship between returns and emissions.

\section{B. Sector Level Impacts}

We now examine the drivers of the event impact on returns outside of the electricity sector. To do this, we first use characteristics that describe sectors as a whole. Coefficients on these sector-average characteristics are consistent with revenue effects, as described in our model, dominating the impact on firm profits. We also include and interact in the regression analysis limited firm-level information of EU Exposure and permit holdings. We find an effect for EU Exposure which we interpret as affecting the magnitude of the revenue effect. We find limited impact of the amount of permits relative to the other factors.

Recall from Section II that the revenue effect depends on how a cost shock in an industry affects the output prices. In order to test the importance of these factors, we again estimate the effects of the price-reduction event, but now decompose the cumulative abnormal returns during the event window by estimating the following equation:

$$
\begin{aligned}
S_{i j t}= & \alpha_{i}+\beta_{i} M_{t}+\delta_{1} E_{V E N T_{t}}+\delta_{2} \text { Dirty }_{j} E_{V E N T}+\delta_{3} E_{i} E_{i} E V N T_{t} \\
& +\delta_{4} \text { Dirty }_{j} E_{i} E_{i} \text { ENT }_{t}+\delta_{5} \text { NoEE }_{i} \text { EVENT }_{t} \\
& +\delta_{6} \text { Dirty }_{j} \text { NoEE }_{i} \text { EVENT }_{t}+\nu_{i j}
\end{aligned}
$$

\footnotetext{
${ }^{16}$ Figure A1 in the online Appendix plots the relationship between the cumulative abnormal returns and each of these variables of interest. We fit linear functions through the data to show the trend. The plots are consistent with the Table 3 results.
} 
where $\beta_{i}$ measures a stock's relationship to the broader index, Dirty $y_{j}$ is a measure of the "dirtiness" of an industry, and $E E_{i}$ is a firm's revenue exposure to the EU market. Because we have European exposure for only a subset of our sample, the dummy variable $N o E E_{i}$ is included to indicate that $E E_{i}$ is missing. Here we cluster the standard errors by two-digit NACE code as this is the level of variation of our primary variables of interest.

We examine two different measures for Dirty $y_{j}$ dirty output $\left(D O_{j}\right)$ measures the carbon intensity, while dirty input $\left(D I_{j}\right)$ measures the electricity and natural gas intensity. In order for $\delta_{1}$ to capture the average effect, we demean $D O_{j}, D I_{j}$, and $E E_{i}$. We describe each of these variables in more detail below.

Dirty output is the average carbon intensity of a sector, measured at the twodigit NACE level. The data sources include the CITL emissions data and Thomson Reuters Datastream financial data. For all sectors $j$, where at least one firm was matched in the CITL, $D O_{j}$ is given by the following formula:

$$
D O_{j}=\frac{\sum_{i \in(j \cap C I T L)} \text { Emit }_{i}}{\sum_{i \in(j \cap C I T L)} S_{i}},
$$

where Emit $_{i}$ is the facility-level emissions in 2005 from the CITL and $S_{i}$ is the 2005 revenue of firm $i$ in thousands of US dollars. We sum over the 124 firms that we identified in the CITL. The subscript $j$ indexes two-digit NACE sectors, and CITL indexes firms contained in the CITL emissions dataset. Emissions intensity for any firm in a given two-digit NACE sector will therefore be based upon the measured emissions of firms matched with CITL data in that sector. There were 345 firms contained in the STOXX 600 index drawn from these sectors.

Dirty input is the average energy intensity of a sector, also measured at the twodigit NACE level. We use input-output tables of industrial activity where we aggregate sectoral expenditures and output in 2004 for the EU-27 countries. ${ }^{17}$ The value $D I_{j}$ is the ratio of expenditures (in 2004 euros) on the utility energy sector (NACE code 40: Electricity, gas, steam, and hot water) over total output (in 2004 euros).

Recall from Section II, the revenue effect depends not only on how dirty an industry is, but whether a firm sells into markets where the bulk of producers are likely to be subject to the regulation. We use the concentration of a firm's revenues in the $\mathrm{EU}$ as a proxy for the exposure of a firm's product markets to the regulation. The variable EU Exposure $\left(E E_{i}\right)$ is the percentage of total sales earned in Europe and proxies for the company's revenue exposure to prices in the EU market. ${ }^{18}$ Note that our theoretical model also pointed out the importance of demand elasticity. To the extent that it captures the exposure of a firm's competitors to the regulation, $E E_{i}$ can

\footnotetext{
${ }^{17}$ Data are reported by the European Commission through the Eurostat system: http://epp.eurostat.ec.europa.eu.

${ }^{18}$ These data come from come from Eurostockcity, who was the data provider to Yahoo Finance UK.
} 
be thought of as a measure of the sensitivity to carbon prices of a firm's residual demand, or the term $P^{\prime} \frac{\partial q_{\neq i}^{*}}{\partial \tau}$ in equation (3). 19

In the sample of 600 firms, roughly 60 percent are in sectors covered by the ETS and therefore have nonzero values for $D O_{j}$. Given that unregulated firms experience effectively no direct carbon-cost exposure, we treated these as equivalent to zero emissions firms. In the case of $E E$, the data were not available for the full sample of firms. Instead, we have measures of EU exposure for 260 firms from 39 two-digit NACE codes. Since we have no information on the EU exposure of the firms with missing data, we include a dummy variable for $N o E E_{i}$.

Table 4 provides the summary statistics for 45 two-digit NACE sectors. For each sector, the table reports average abnormal returns during the event window. In addition, we report the sectoral characteristics $D O_{j}$ and $D I_{j}$, and the sectoral means for $E E_{i}, N o E E_{i}$, and market capitalization. The mining, metals, and paper sectors are the most utility energy intensive after the power sector: with mining experiencing some of the largest abnormal declines during the event window. Utilities have the highest carbon emissions intensity: its average stocks had an abnormal decline of about 1.7 percent. The total number of firms in our estimating sample is reduced from 600 to 552 due to incomplete stock data for 48 firms.

Results.-Table 5 reports the results of different variations of (5). The overall event produced a 0.5 percent decline for the full sample. The second and third columns report the results controlling only for dirty output or dirty input, respectively. The fourth column controls only for EU Exposure and an indicator of missing exposure data. Column 5 includes both dirty measures. The sixth and seventh columns interact either $D O$ or $D I$ with EU exposure, under the intuition that a revenue effect would be strongest in relatively "dirty" industries that are also heavily concentrated in the European market. The last column includes all variables.

From Table 5, there is a weak relationship between carbon intensity and performance during the event window. Firms from industries with high emissions (large $D O$ ) or relatively dirty inputs (e.g., high electricity and gas usage) saw their share prices decline. This is suggestive of a larger revenue effect in dirtier industries. Firms in dirty sectors will have experienced a decline in their competitor's, as well as their own, marginal costs. In column 5, both $D O$ and $D I$ measures are included. By controlling for $D I$, the effect from $D O$ becomes stronger, now significant at the 10 percent level.

It might at first seem counterintuitive that the firms most directly impacted by $\mathrm{CO}_{2}$ regulations would be the greatest losers from a decline in $\mathrm{CO}_{2}$ prices. Recall that these values are measuring the relative carbon intensities of industries, not the individual firms within industries. Thus, we interpret these results as being consistent with the hypothesis that product prices, and therefore revenues, were negatively impacted by the $\mathrm{CO}_{2}$ price shock. Although costs were also reduced, either through the direct or indirect exposure to $\mathrm{CO}_{2}$ regulation, it appears that the revenue effects were stronger. For regulated industries, this is almost certainly a consequence of the

\footnotetext{
${ }^{19}$ In a previous draft of this paper, we used measures of trade exposure to proxy for elasticity but found insignificant results with these proxies. Unlike the trade data, the EU exposure variable provides us with firm-level variation as well as broader coverage of nongoods sectors.
} 
TABle 4-Summary Statistics By INDUSTRY

\begin{tabular}{|c|c|c|c|c|c|c|}
\hline Industry description & $\begin{array}{l}\text { Event } \\
\text { return }\end{array}$ & $\begin{array}{l}\text { Dirty } \\
\text { output }\end{array}$ & $\begin{array}{l}\text { Dirty } \\
\text { input }\end{array}$ & $\begin{array}{l}\text { Avg. EU } \\
\text { exposure }\end{array}$ & $\begin{array}{l}\text { Fraction } \\
\text { missing EE }\end{array}$ & $\begin{array}{c}\text { Market } \\
\text { cap }\end{array}$ \\
\hline Coal and lignite mining & -0.032 & 0.006 & 0.083 & 0.165 & 0.000 & 58,800 \\
\hline Crude petroleum extraction & -0.032 & 0.126 & 0.008 & 0.491 & 0.200 & 32,400 \\
\hline Basic metals & -0.031 & 0.416 & 0.039 & 0.565 & 0.067 & 10,500 \\
\hline Sewage and refuse & -0.027 & 0.000 & 0.011 & 1.000 & 0.000 & 2,910 \\
\hline Water transport & -0.027 & 0.000 & 0.002 & \#N/A & 1.000 & 5,880 \\
\hline Refining and coke & -0.027 & 0.024 & 0.010 & 0.585 & 0.000 & 132,000 \\
\hline Computer manufacturing & -0.023 & 0.000 & 0.005 & $\# \mathrm{~N} / \mathrm{A}$ & 1.000 & 3,830 \\
\hline Metal ores mining & -0.023 & 0.012 & 0.057 & 0.493 & 0.000 & 16,500 \\
\hline Tobacco manufacturing & -0.019 & 0.000 & 0.009 & $\# \mathrm{~N} / \mathrm{A}$ & 1.000 & 26,600 \\
\hline Electricity and gas & -0.017 & 0.975 & 0.204 & 0.865 & 0.077 & 21,400 \\
\hline Real estate & -0.016 & 0.038 & 0.005 & 0.980 & 0.875 & 4,990 \\
\hline Water & -0.016 & 0.000 & 0.051 & 0.920 & 0.000 & 11,100 \\
\hline Land transport & -0.011 & 0.000 & 0.011 & 0.540 & 0.600 & 3,440 \\
\hline Rubber and plastics & -0.010 & 0.023 & 0.023 & 0.690 & 0.667 & 9,900 \\
\hline Computer activities & -0.009 & 0.005 & 0.003 & 0.665 & 0.818 & 10,300 \\
\hline Other transport & -0.009 & 0.001 & 0.009 & 0.423 & 0.125 & 12,100 \\
\hline Hotels and restaurants & -0.009 & 0.000 & 0.012 & $\# \mathrm{~N} / \mathrm{A}$ & 1.000 & 6,790 \\
\hline Motor vehicles & -0.008 & 0.023 & 0.008 & 0.592 & 0.455 & 19,100 \\
\hline Radio and TV & -0.008 & 0.001 & 0.008 & 0.504 & 0.583 & 17,700 \\
\hline Electrical machinery & -0.007 & 0.001 & 0.012 & 0.506 & 0.167 & 25,200 \\
\hline Retail trade & -0.006 & 0.000 & 0.015 & 0.987 & 0.842 & 13,400 \\
\hline Construction & -0.006 & 0.010 & 0.002 & 0.726 & 0.357 & 6,900 \\
\hline Medical instruments & -0.005 & 0.002 & 0.006 & 0.483 & 0.529 & 6,550 \\
\hline Publishing and printing & -0.004 & 0.000 & 0.010 & 0.360 & 0.889 & 7,970 \\
\hline Air transport & -0.003 & 0.006 & 0.002 & 0.610 & 0.800 & 6,100 \\
\hline Pulp and paper & -0.003 & 0.143 & 0.044 & 0.773 & 0.200 & 7,550 \\
\hline Food manufacturing & -0.003 & 0.008 & 0.015 & 0.495 & 0.905 & 20,800 \\
\hline Other business activities & -0.001 & 0.105 & 0.004 & 0.742 & 0.536 & 20,200 \\
\hline Auxiliary financials & 0.000 & 0.000 & 0.004 & 1.000 & 0.778 & 6,990 \\
\hline Machinery & 0.000 & 0.002 & 0.010 & 0.490 & 0.111 & 7,410 \\
\hline Chemicals & 0.000 & 0.020 & 0.023 & 0.544 & 0.342 & 24,200 \\
\hline Financial intermediation & 0.001 & 0.000 & 0.003 & 0.836 & 0.833 & 20,600 \\
\hline Apparel manufacturing & 0.002 & 0.000 & 0.008 & $\# \mathrm{~N} / \mathrm{A}$ & 1.000 & 21,700 \\
\hline Post and telecomm & 0.002 & 0.000 & 0.008 & 0.906 & 0.741 & 26,400 \\
\hline Furniture & 0.003 & 0.000 & 0.010 & 0.460 & 0.333 & 12,100 \\
\hline Insurance & 0.004 & 0.000 & 0.002 & 0.826 & 0.808 & 18,200 \\
\hline Recreational and cultural & 0.005 & 0.023 & 0.010 & $\# \mathrm{~N} / \mathrm{A}$ & 1.000 & 8,150 \\
\hline Health and social work & 0.007 & 0.000 & 0.008 & 1.000 & 0.000 & 2,370 \\
\hline Tanning leather & 0.007 & 0.000 & 0.009 & 0.420 & 0.000 & 10,500 \\
\hline Fabricated metals & 0.008 & 0.010 & 0.015 & 0.663 & 0.000 & 6,060 \\
\hline Nonmetallic manufacturing & 0.009 & 0.416 & 0.043 & 0.494 & 0.000 & 12,500 \\
\hline Wholesale trade & 0.010 & 0.000 & 0.006 & 0.780 & 0.286 & 5,050 \\
\hline Supporting transport & 0.014 & 0.088 & 0.006 & 0.816 & 0.300 & 7,080 \\
\hline Other mining & 0.016 & 0.073 & 0.039 & 0.750 & 0.000 & 5,310 \\
\hline Renting machinery & 0.022 & 0.000 & 0.004 & 0.590 & 0.000 & 1,450 \\
\hline All industries & -0.005 & 0.087 & 0.020 & 0.655 & 0.529 & 16,600 \\
\hline
\end{tabular}

Notes: The table reports the sample mean for each two-digit NACE sector. Dirty Output, Dirty Input, and EU Exposure are defined in the text. Market cap is equity value in millions of US dollars on April 25, 2006.

fact that allocations were closely linked to emissions, as illustrated above. For these firms, the revenue effects would naturally be the strongest as the reductions in costs are largely offset by a concurrent reduction in the value of permit holdings.

This conclusion becomes more clear when we examine the interaction of $D O$ and $D I$ with a firm's exposure to the EU market. First note that, by itself, EU Exposure is an insignificant determinant of the event impact, and the indicator of whether a firm is missing $E E$ data is also insignificant (see column 4). In column 6, $D O$ is interacted with EU exposure. The interaction term between $D O$ and $E E$ is highly significant and negative while the $D O$ coefficient is no longer significant. The interaction 
Table 5-Heterogeneous Event Study by Industry Characteristics

\begin{tabular}{|c|c|c|c|c|c|c|c|c|}
\hline & (1) & (2) & (3) & (4) & (5) & (6) & (7) & (8) \\
\hline Event & $\begin{array}{l}-0.005^{* * * *} \\
(0.002)\end{array}$ & $\begin{array}{c}-0.005^{* * * *} \\
(0.002)\end{array}$ & $\begin{array}{l}-0.005 * * * \\
(0.002)\end{array}$ & $\begin{array}{c}-0.007 * * \\
(0.003)\end{array}$ & $\begin{array}{l}-0.005^{* * * *} \\
(0.002)\end{array}$ & $\begin{array}{c}-0.005^{*} \\
(0.002)\end{array}$ & $\begin{array}{c}-0.005^{*} \\
(0.003)\end{array}$ & $\begin{array}{r}-0.005^{*} \\
(0.003)\end{array}$ \\
\hline $\begin{array}{c}\text { Dirty output } \\
\times \text { event }\end{array}$ & & $\begin{array}{c}-0.017 * * * \\
(0.006)\end{array}$ & & & $\begin{array}{r}-0.018 \\
(0.031)\end{array}$ & $\begin{array}{c}-0.008 \\
(0.007)\end{array}$ & & $\begin{array}{l}-0.03 \\
(0.036)\end{array}$ \\
\hline $\begin{array}{l}\text { Dirty input } \\
\times \text { event }\end{array}$ & & & $\begin{array}{c}-0.08 * * * \\
(0.019)\end{array}$ & & $\begin{array}{c}0.003 \\
(0.146)\end{array}$ & & $\begin{array}{c}-0.054 \\
(0.045)\end{array}$ & $\begin{array}{c}0.101 \\
(0.178)\end{array}$ \\
\hline $\begin{array}{c}\text { EU exposure } \\
\times \text { event }\end{array}$ & & & & $\begin{array}{c}0.011 \\
(0.013)\end{array}$ & & $\begin{array}{c}0.019 * \\
(0.011)\end{array}$ & $\begin{array}{c}0.017 \\
(0.012)\end{array}$ & $\begin{array}{c}0.019^{*} \\
(0.011)\end{array}$ \\
\hline $\begin{array}{l}\text { Missing exposure } \\
\times \text { event }\end{array}$ & & & & $\begin{array}{c}0.003 \\
(0.003)\end{array}$ & & $\begin{array}{l}0 \\
(0.002)\end{array}$ & $\begin{array}{c}0.001 \\
(0.002)\end{array}$ & $\begin{array}{c}0.001 \\
(0.002)\end{array}$ \\
\hline $\begin{array}{l}\text { DO } \times \text { exposure } \\
\quad \times \text { event }\end{array}$ & & & & & & $\begin{array}{l}-0.081^{* * * *} \\
(0.026)\end{array}$ & & $\begin{array}{r}-0.18^{*} \\
(0.092)\end{array}$ \\
\hline $\begin{array}{c}\mathrm{DO} \times \text { missing } \\
\times \text { event }\end{array}$ & & & & & & $\begin{array}{c}-0.005 \\
(0.012)\end{array}$ & & $\begin{array}{c}-0.008 \\
(0.030)\end{array}$ \\
\hline $\begin{array}{l}\text { DI } \times \text { exposure } \\
\quad \times \text { event }\end{array}$ & & & & & & & $\begin{array}{c}-0.238 \\
(0.162)\end{array}$ & $\begin{array}{c}0.553 \\
(0.477)\end{array}$ \\
\hline $\begin{array}{l}\text { DI } \times \text { missing } \\
\times \text { event }\end{array}$ & & & & & & & $\begin{array}{c}0.044 \\
(0.051)\end{array}$ & $\begin{array}{c}0.055 \\
(0.155)\end{array}$ \\
\hline
\end{tabular}

Notes: Firm fixed effects and firm-specific "betas" (coefficients on market returns) are not shown. The dependent variable is the daily percent change in a stock's price. Standard errors are clustered by two-digit NACE codes. There are 552 firms and 249,844 observations.

*** Significant at the 1 percent level.

** Significant at the 5 percent level.

* Significant at the 10 percent level.

between $N o E E$ and $D O$ is insignificant. As we have demeaned the continuous variables, this suggests that the firms not reporting $E E$ are similar to the average firm that does report. Overall, these findings imply that it was firms with high EU exposure who were largely driving the negative value on $D O$ seen in column 2. Firms that were both highly concentrated in Europe and selling products produced by dirty industries experienced the sharpest declines. In column 7, the coefficients on the interaction between $D I$ and $E E$ are large in magnitude but imprecisely estimated. The full model is consistent with column 6 results but less precisely estimated.

In Table A4 of the online Appendix, we examine the robustness of these results in several ways. The first two columns repeat our main coefficients for columns 5 and 6 of Table 5, but use two-way clustered standard errors (by firm and date). Column 1 suggests that with both $D O$ and $D I, D O$ is significant at the six percent level. Column 2 supports the main results. Columns 3 and 4 examine the big event window consisting of five days prior and 25 days after April 25, 2006 and perform the same analysis as (5). We find qualitatively similar results as in Table 5, though much less precisely estimated. For example, there was a two percent reduction in the average stock performance. Interestingly, the impacts of EU exposure are much stronger than during the shorter event window. While firms in "clean" industries with EU exposure do better during the event, the coefficient on the interaction of "dirty" and EU exposure is still negative but no longer significant. The overall market experienced much larger declines during the large window, while those concentrated in Europe performed disproportionately better. The last two columns repeat the analysis for a two-year period centered around a counterfactual three-day "event" beginning 
April 25, 2004-before the market had even begun. No coefficients are significant in this placebo test.

We perform further specification robustness checks not reported in this table. As in Table 2, we find that including a firm's debt-to-equity ratio interacted with the event window. Although debt-to-equity is significant, it does not change the underlying picture with regards to dirty inputs and outputs during the short event window. We also find similar results when just testing the event on the unadjusted cumulative returns (e.g., no $\beta$ term) of the shares. We also examine the sensitivity of the results to the power and heat sector. Recall that this sector was one of the "dirtiest" in terms of both outputs and inputs. When the power and heat sector (NACE 4011) is excluded, the results are qualitatively similar: the interaction between $E E$ and $D O$ is of similar sign and magnitude but noisier. In particular, the coefficient is significant with robust standard errors, while they are insignificant when standard errors are clustered by two-digit NACE code. Finally, additional robustness tests not reported here examine possible spillovers to the United States, and run falsification tests for a previous spring. ${ }^{20}$

Asset Value of Permit Holdings.-Finally, we examine the effect of firm-level permit allocation and emissions on the performance of share prices during the event. Building upon the standard business rhetoric that views the costs of a regulation as driven by the asset value of permit holdings, we investigate and find that the permit price effects are not strong relative to the revenue effect. Using the CITL data described in Section IIIA, we modify equation (5) to include firm-level initial allocation of allowances and emissions:

$$
\begin{aligned}
S_{i j t}= & \alpha_{i}+\beta_{i} M_{t}+\delta_{1} \text { EVENT }_{t}+\delta_{2} \text { Dirty }_{j} \text { EVENT }_{t}+\delta_{3} E_{i} E_{i} \text { EVNT }_{t} \\
& +\delta_{4} \text { Dirty }_{j} E_{i} E_{\text {EVENT }}+\delta_{5} \text { NoEE }_{i} \text { EVENT }_{t} \\
& +\delta_{6} \text { Dirty }_{j} \text { NoEE }_{i} \text { EVENT }_{t} \\
& +\mu \times\left(\frac{A_{i}-E_{i}}{C_{i}}\right) \text { EVENT }_{t}+\psi \text { MissNA }_{i}+\varepsilon_{i j},
\end{aligned}
$$

where the new variables are defined as: $A_{i}$ is allowances, $E_{i}$ is emissions, $C_{i}$ is market capitalization, and $\operatorname{MissN}_{i}$ is a dummy variable that indicates a firm is missing net allowance data. In particular, we modify the main model of column 6 of Table 5.

In our model, given a drop in permit prices, those firms with a more positive net permit positions $\left(A_{i}>E_{i}\right)$ will lose more profits than others with fewer, all

\footnotetext{
${ }^{20}$ In Bushnell, Chong, and Mansur (2009), we replicate the analysis using US data for the stocks in the US Standard and Poors 500 index. When all factors are considered, the only variable with a significant impact on returns is the $D O$ index variable, which is positive, indicating that dirty firms experienced an increase relative to cleaner firms during this period. However, the United States may not be a clean control group due to the large number of multinational firms, linkages of product markets through international trade, and political impacts. We have also replicated the analysis using a similar time frame from the year 2004, a date before the $\mathrm{EU} \mathrm{CO}_{2}$ market came into existence, as a form of falsification test. Although certain characteristics were significant in determining the abnormal returns of shares during this 2004 "falsification" period, the results are quite different from the results from the $2006 \mathrm{CO}_{2}$ price crash.
} 
Table 6-Firm-Level Permit Allowances and Emissions

\begin{tabular}{|c|c|c|c|c|c|c|c|c|}
\hline & (1) & (2) & (3) & (4) & (5) & (6) & (7) & (8) \\
\hline Event & $\begin{array}{l}-0.007 * * * \\
(0.002)\end{array}$ & $\begin{array}{l}-0.006 * * * \\
(0.002)\end{array}$ & $\begin{array}{l}-0.006 * * * \\
(0.002)\end{array}$ & $\begin{array}{c}-0.006^{* *} \\
(0.002)\end{array}$ & $\begin{array}{c}-0.007 * * \\
(0.003)\end{array}$ & $\begin{array}{l}-0.012 * * * \\
(0.003)\end{array}$ & $\begin{array}{l}-0.013 * * * \\
(0.003)\end{array}$ & $\begin{array}{l}-0.013 * * * \\
(0.003)\end{array}$ \\
\hline $\begin{array}{c}\text { Dirty output } \\
\times \text { event }\end{array}$ & $\begin{array}{c}-0.007 \\
(0.007)\end{array}$ & $\begin{array}{c}-0.009 \\
(0.007)\end{array}$ & $\begin{array}{c}-0.01 \\
(0.007)\end{array}$ & $\begin{array}{r}-0.010 \\
(0.007)\end{array}$ & $\begin{array}{r}-0.006 \\
(0.008)\end{array}$ & $\begin{array}{c}-0.003 \\
(0.008)\end{array}$ & $\begin{array}{c}-0.002 \\
(0.008)\end{array}$ & $\begin{array}{c}-0.002 \\
(0.008)\end{array}$ \\
\hline $\begin{array}{c}\text { EU exposure } \\
\times \text { event }\end{array}$ & $\begin{array}{c}0.019 * \\
(0.011)\end{array}$ & $\begin{array}{c}0.018 \\
(0.011)\end{array}$ & $\begin{array}{c}0.018 \\
(0.011)\end{array}$ & $\begin{array}{c}0.018 \\
(0.011)\end{array}$ & $\begin{array}{c}0.019 * \\
(0.011)\end{array}$ & $\begin{array}{c}0.019 * \\
(0.011)\end{array}$ & $\begin{array}{c}0.019 * \\
(0.011)\end{array}$ & $\begin{array}{c}0.019 * \\
(0.011)\end{array}$ \\
\hline $\begin{array}{l}\text { Missing exposure } \\
\quad \times \text { event }\end{array}$ & $\begin{array}{c}-0.001 \\
(0.002)\end{array}$ & $\begin{array}{c}0.000 \\
(0.002)\end{array}$ & $\begin{array}{c}0.000 \\
(0.002)\end{array}$ & $\begin{array}{c}0.000 \\
(0.002)\end{array}$ & $\begin{array}{c}-0.001 \\
(0.002)\end{array}$ & $\begin{array}{c}-0.001 \\
(0.003)\end{array}$ & $\begin{array}{c}-0.001 \\
(0.002)\end{array}$ & $\begin{array}{c}-0.001 \\
(0.003)\end{array}$ \\
\hline $\begin{array}{l}\mathrm{DO} \times \text { exposure } \\
\quad \times \text { event }\end{array}$ & $\begin{array}{l}-0.083 * * * \\
(0.028)\end{array}$ & $\begin{array}{l}-0.088^{* * * *} \\
(0.024)\end{array}$ & $\begin{array}{c}-0.09^{* * *} * \\
(0.024)\end{array}$ & $\begin{array}{l}-0.093 * * * \\
(0.025)\end{array}$ & $\begin{array}{l}-0.082^{* * * *} \\
(0.028)\end{array}$ & $\begin{array}{c}-0.103 * * * \\
(0.032)\end{array}$ & $\begin{array}{l}-0.105^{* * *} \\
(0.033)\end{array}$ & $\begin{array}{l}-0.104 * * * \\
(0.034)\end{array}$ \\
\hline $\begin{array}{l}\text { DO } \times \text { missing } \\
\times \text { event }\end{array}$ & $\begin{array}{c}-0.006 \\
(0.012)\end{array}$ & $\begin{array}{c}-0.004 \\
(0.013)\end{array}$ & $\begin{array}{c}-0.003 \\
(0.012)\end{array}$ & $\begin{array}{c}-0.003 \\
(0.012)\end{array}$ & $\begin{array}{r}-0.006 \\
(0.012)\end{array}$ & $\begin{array}{c}-0.010 \\
(0.013)\end{array}$ & $\begin{array}{r}-0.010 \\
(0.013)\end{array}$ & $\begin{array}{r}-0.010 \\
(0.013)\end{array}$ \\
\hline Net $\times$ event & $\begin{array}{r}-15.605 \\
(9.445)\end{array}$ & & & & & & & \\
\hline Allow $\times$ event & & $\begin{array}{l}4.752 * * \\
(2.355)\end{array}$ & & $\begin{array}{l}-8.978 \\
(15.584)\end{array}$ & & & & \\
\hline Emit $\times$ event & & & $\begin{array}{l}4.900^{* *} \\
(1.870)\end{array}$ & $\begin{array}{c}13.594 \\
(13.325)\end{array}$ & & & & \\
\hline $\begin{array}{l}\text { Net } \times \text { electric } \\
\times \text { event }\end{array}$ & & & & & $\begin{array}{c}-12.465 \\
(11.414)\end{array}$ & & & \\
\hline $\begin{array}{l}\text { Allow } \times \text { electric } \\
\quad \times \text { event }\end{array}$ & & & & & & $\begin{array}{l}8.033 * * * \\
(0.680)\end{array}$ & & $\begin{array}{l}5.476 \\
(6.094)\end{array}$ \\
\hline $\begin{array}{l}\text { Emit } \times \text { electric } \\
\times \text { event }\end{array}$ & & & & & & & $\begin{array}{l}7.896^{* * * *} \\
(0.773)\end{array}$ & $\begin{array}{c}2.652 \\
(6.681)\end{array}$ \\
\hline $\begin{array}{l}\text { Net } \times \text { other } \\
\quad \times \text { event }\end{array}$ & & & & & $\begin{array}{c}-21.593 \\
(25.008)\end{array}$ & & & \\
\hline $\begin{array}{l}\text { Allow } \times \text { other } \\
\times \text { event }\end{array}$ & & & & & & $\begin{array}{c}-21.323^{* * * *} \\
(6.484)\end{array}$ & & $\begin{array}{c}5.755 \\
(15.822)\end{array}$ \\
\hline $\begin{array}{c}\text { Emit } \times \text { other } \\
\quad \times \text { event }\end{array}$ & & & & & & & $\begin{array}{l}-24.577 * * *- \\
(7.238)\end{array}$ & $\begin{array}{c}-30.735^{*} \\
(15.654)\end{array}$ \\
\hline $\begin{array}{l}\text { Missing net emit } \\
\times \text { event }\end{array}$ & $\begin{array}{c}0.003 \\
(0.003)\end{array}$ & $\begin{array}{c}0.003 \\
(0.003)\end{array}$ & $\begin{array}{c}0.002 \\
(0.003)\end{array}$ & $\begin{array}{c}0.002 \\
(0.003)\end{array}$ & $\begin{array}{c}0.003 \\
(0.003)\end{array}$ & $\begin{array}{l}0.009^{* *} \\
(0.004)\end{array}$ & $\begin{array}{l}0.010 * * \\
(0.004)\end{array}$ & $\begin{array}{l}0.010^{* *} \\
(0.004)\end{array}$ \\
\hline
\end{tabular}

Note: See Table 5.

else equal. The net permit position $\left(A_{i}-E_{i}\right)$ is normalized by market capitalization. This is done because larger firms could have greater variation of net permits. Furthermore, this normalization implies a $\mu$ coefficient of the change in market capitalization given a change in net permits.

One hypothesis likens the cost of a regulation to the change in the price of permits. If profit impacts were driven completely by net emissions costs, we hypothesize that the coefficient $\mu$ would equal roughly the drop in permit price times three, or -42 . A firm with, for example, one million tonnes of excess permits in 2005 may be expected to have extra permits in 2006 and 2007. The value of these unused permits fell by the drop in the permit price, which was around $€ 14$. Hence, this hypothetical firm would have lost $€ 42$ million: 1 million tonnes/year $\times 3$ years $\times-€ 14 /$ tonne.

Table 6 reports our estimates. Column 1 estimates equation (7). The coefficient on net positions is not statistically different from zero and is statistically different from -42 at the 5 percent significance level. Columns 2 through 8 report different analyses of the impact of permit allocations. In columns 2 through 4, we separate emissions 
and allocations while still normalizing by market capitalization. Firms with more emissions liabilities statistically significantly benefited when the stock price fell (column 3), but the coefficient on allowances is also positive (column 2). The two coefficients are similar because allocations and emissions are highly colinear, as described in Figure 4. When both variables are included (column 4), both coefficients are not statistically different from zero, as would be expected from the colinearity.

Columns 5 through 8 of Table 6 look at the heterogeneity of the asset holding variables between industries that were short permits (the electricity sector) versus industries that were long. The preceding analysis is repeated with an interaction of the asset holding variables with whether the firm was in the electricity sector or not. The net allowance position (column 5) is similarly negative with large standard errors. When including allowances or emissions separately (column 6 and 7), the sign of the coefficient is statistically significantly different from zero but of opposite sign between electricity and other firms. For the electricity sector, the cleaner firms suffered more from the price drop. For the other sectors, the dirtier firms suffered more. Again, coefficient estimates between column 6 and 7 are similar due to the colinearity, so the mechanism cannot be separated. When both allowances and emissions are included together (column 8 ), the results are mostly not statistically significant and the signs differ between columns 4 and 8 .

The results on permit allocation are noisy and should not be interpreted too strongly because of data issues. Net permit position information is only available for 124 of the firms. Incomplete matching of emission data to firms could mean that a firm that has matched one installation may have many more emissions. There is also limited variation on net allocation, as the emissions and allowances are close. Online Appendix Table A1 shows the variation in emissions, allocation, and net position by industry.

Table 6 does show that the estimates of the main result, the revenue effect, is not highly affected by including permit allowances. In particular, the Dirty Output $\times$ Exposure coefficients are stable across the specifications. While we do not have sufficient variation to rule out that permit holdings had some effect, our results imply that investors focus on product price impacts, rather than just compliance costs and the nominal value of pollution permits.

\section{Conclusions}

The development and application of any significant new environmental regulation will involve some level of debate over its economic impacts. This is particularly true in the case of regulations to combat climate change because the stakes are so high. The annual value of permits consumed in the European ETS market we study reached nearly $\$ 60$ billion. A market in the United States would be two to three times the size of the European market. These values are an order of magnitude larger than any other previous emissions trading markets. These sums have generated intense interest in the potential incidence of these costs, and many industries are making the case for some form of free permit allocation to offset these costs.

However, the cost impact is only one part of the story from the perspective of firms and industries. The impact of emissions costs on revenues is another critical consideration. The policy implications of this full spectrum of impacts has drawn us to 
examine the European ETS market. Our event-study approach analyzes the response of the stock market to the devaluation of $\mathrm{CO}_{2}$ permit prices in late April 2006 . This provides one of the first opportunities to empirically test the impacts of $\mathrm{CO}_{2}$ regulation on major industries and firms. By looking at the impact of a sharp decline in $\mathrm{CO}_{2}$ prices on the equity prices of impacted firms, we can get a strong sense of what the market believes to be the net impacts of $\mathrm{CO}_{2}$ regulations.

The story that emerges from an examination of this event is that the equity markets were strongly focused on revenue effects. Our results demonstrate, fairly robustly, that the share prices of firms from the "dirtiest" industries experienced the largest abnormal declines during this period.

Within the power sector, which was as a whole "short" of permits, the share prices of firms with the highest emissions rates, perform better than the "cleaner" firms within this sector. The share prices of many of these high emissions firms did experience abnormal declines, but these declines were less severe than those of their low carbon intensity competitors. The fact that very low-carbon emissions electricity firms declined the most gives strong indication that the market understood how declining $\mathrm{CO}_{2}$ prices would reduce the revenues of these firms through lower electricity prices. High emissions firms still experienced declines despite a lessening of regulation. This highlights the fact that the market revenue effects outweighed their cost savings from lower $\mathrm{CO}_{2}$ prices, including any allowance effects. Within other industries that were in aggregate allocated more allowances than were consumed, those firms with the largest allowances experienced the largest abnormal declines.

It is important to recognize the many caveats that must be applied to interpreting these results. The ETS was a very new market, which was one of the causes of the variation in the emissions permit price that we utilize here. It would be heroic to assume that the stock market completely and accurately processed the information that emerged in late April 2006. In addition, while the crash affected both near-term and long-term $\mathrm{CO}_{2}$ prices, the impact on the near-term Phase I prices was much more pronounced. The events of 2006 may also have impacted expectations about future allocations of emissions permits, as well as expectations about prices. Because our event study uses the same time window for all stocks, any contemporaneous events could also be causing the abnormal returns. We looked for sector-specific announcements in this period. Specifically, oil prices did not change dramatically.

Nonetheless, these results are largely consistent with what simulation studies had predicted could be the case for many of these industries. These studies forecast an increase in revenues that would largely offset the increase in regulatory costs. In fact, our results imply that for clean firms in dirty industries like electricity, these revenue effects are larger than cost increases. These are important facts to bear in mind when setting policies regarding allocations to impacted industries. In many cases, those directly or even indirectly impacted by $\mathrm{CO}_{2}$ costs may need little compensation. Instead, it is their customers who will be most affected. 


\section{APPENDIX}

\section{A Model of Impacts of Allowance Prices on Profits}

This Appendix presents a static theory model representing the channels through which profits can be impacted by an exogenous change in environmental costs (e.g., permit prices).

Recall equation (2) in the text: firm $i$ profits are

$$
\pi_{i}=P\left(q_{i}+q_{\neq i}\right) q_{i}-C_{i}\left(q_{i}, \omega\right)+\tau A_{i}-\tau r_{i}\left(q_{i}, I_{i}\right) q_{i}-k\left(I_{i}\right) .
$$

The impact on profits of a marginal change in $\tau$ can be expressed as

$$
\begin{aligned}
\frac{d \pi_{i}}{d \tau}= & P \frac{d q_{i}}{d \tau}+P^{\prime} \cdot\left[\frac{d q_{i}}{d \tau}+\frac{d q_{\neq i}}{d \tau}\right] q_{i}-\frac{\partial C_{i}}{\partial q_{i}} \frac{\partial q_{i}}{\partial \tau}-\frac{\partial C_{i}}{\partial \omega} \frac{\partial \omega}{\partial \tau} \\
& +A_{i}-r_{i} q_{i}-\tau\left(\frac{\partial r_{i}}{\partial q_{i}} q_{i}+r_{i}\right) \frac{d q_{i}}{d \tau}-\left(\tau \frac{\partial r_{i}}{\partial I_{i}} q_{i}+k^{\prime}\left(I_{i}\right)\right) \frac{d I_{i}}{d \tau} .
\end{aligned}
$$

This effect applies to incremental changes in $\tau$. Large changes in $\tau$ would require integrating over this function, however for changes in $\tau$ that result in marginal changes in $q_{i}$ and $I_{i}$ we can apply the envelope theorem to further simplify this expression. Assuming that firms maximize profits with respect to $q$, we can write the optimal output $q_{i}^{*}$ as a function, $f(\cdot)$, of the competitors' production, the direct effect of the permit price, and the indirect effect through input prices: $q_{i}^{*}$ $=f\left(q_{\neq i}, \tau, \omega(\tau)\right)$. Next, define $\pi_{i}^{*} \equiv \pi_{i}\left(q_{i}^{*}\right)$. For shocks that have marginal influence on $q_{i}$, the envelope theorem implies

$$
\frac{\partial \pi_{i}^{*}}{\partial q_{i}}=P+P^{\prime} q_{i}^{*}-\frac{\partial C_{i}}{\partial q_{i}}-\tau\left(r_{i}^{\prime} q_{i}^{*}+r_{i}\right)=0 .
$$

In other words, the change in profitability through own output would be negligible. Similarly, the last term of (A1) articulates the change in emissions and capital costs resulting from a change in abatement investment, $I_{i}$. At an optimal level of abatement, where $\frac{\partial \pi_{i}}{\partial I_{i}^{*}}=0$, a firm would set its marginal cost of abatement equal to the marginal cost of emissions.

$$
\tau \frac{\partial r_{i}}{\partial I_{i}^{*}} q_{i}-k^{\prime}\left(I_{i}^{*}\right)=0 .
$$

Again assuming that investment $I$ is relatively inelastic to local changes in $\tau$, the last term in (A1) becomes zero. However, there are still effects relating to changes in market prices due to the responses of other firms in the industry, direct costs, and the value of net allowance holdings. This can be seen by combining equations (2), (A2), and (A3):

$$
\frac{d \pi_{i}^{*}}{d \tau}=P^{\prime} \frac{d q_{\neq i}}{d \tau} q_{i}^{*}-\frac{\partial C_{i}}{\partial \omega} \frac{d \omega}{d \tau}+A_{i}-r_{i} q_{i}^{*}
$$


Finally, by recognizing that each firm's optimal output response can be written as a $f(\cdot)$ function, we define the effect of a change in $\tau$ on other firms' output as the sum of a direct component and an indirect effect through input prices:

$$
\frac{d q_{\neq i}^{*}}{d \tau}=\frac{\partial q_{\neq i}^{*}}{\partial \tau}+\frac{\partial q_{\neq i}^{*}}{\partial \omega} \frac{\partial \omega}{\partial \tau} .
$$

From this, we derive equation (3) that we restate here:

$$
\frac{d \pi_{i}^{*}}{d \tau}=P^{\prime} \frac{\partial q_{\neq i}^{*}}{\partial \tau} q_{i}^{*}+\left[P^{\prime} \frac{\partial q_{\neq i}^{*}}{\partial \omega} q_{i}^{*}-\frac{\partial C}{\partial \omega}\right] \frac{\partial \omega}{\partial \tau}+\left[A_{i}-r_{i} q_{i}^{*}\right]
$$

\section{REFERENCES}

Beatty, Timothy, and Jay P. Shimshack. 2010. "The Impact of Climate Change Information: New Evidence from the Stock Market." B. E. Journal of Economic Analysis \& Policy: Contributions 10 (1): Article 60.

Becker, Randy, and Vernon Henderson. 2000. "Effects of Air Quality Regulations on Polluting Industries." Journal of Political Economy 108 (2): 379-421.

-Betz, Regina, Wolfgang Eichhammer, and Joachim Schleich. 2004. "Designing National Allocation Plans for EU Emissions Trading - A First Analysis of the Outcome." Energy \& Environment 15 (3): 375-425.

Bovenberg, A. Lans, and Lawrence H. Goulder. 2001. "Neutralizing the Adverse Industry Impacts of $\mathrm{CO}_{2}$ Abatement Policies: What Does It Cost?" In Behavioral and Distributional Effects of Environmental Policy, edited by Carlo Carraro and Gilbert E. Metcalf, 45-85. Chicago: University of Chicago Press.

Brown, Stephen J., and Jerold B. Warner. 1985. "Using daily stock returns: The case of event studies." Journal of Financial Economics 14 (1): 3-31.

Bushnell, James B., Howard Chong, and Erin T. Mansur. 2009. "Profiting from Regulation: An Event Study of the EU Carbon Market." National Bureau of Economic Research (NBER) Working Paper 15572.

Bushnell, James B., Howard Chong, and Erin T. Mansur. 2013. "Profiting from Regulation: Evidence from the European Carbon Market: Dataset." American Economic Journal: Economic Policy. http://dx.doi.org/10.1257/pol.5.4.78

Burtraw, Dallas, and Karen L. Palmer. 2008. "Compensation rules for climate policy in the electricity sector." Journal of Policy Analysis and Management 27 (4): 819-47.

Cameron, A. Colin, Jonah B. Gelbach, and Douglas L. Miller. 2011. "Robust Inference With Multiway Clustering." Journal of Business and Economic Statistics 29 (2): 238-49.

Convery, Frank, Denny Ellerman, and Christian De Perthuis. 2008. The European Carbon Market in Action: Lessons from the First Trading Period. Report 162. MIT Joint Program on the Science and Policy of Global Change. Cambridge, MA, June.

Corrado, Charles J. 2011. "Event studies: A methodology review." Accounting and Finance 51 (1): 207-34.

Dasgupta, Susmita, Jong Ho Hong, Benoit Laplante, and Nlandu Mamingi. 2006. "Disclosure of environmental violations and stock market in the Republic of Korea." Ecological Economics 58 (4): 759-77.

Dasgupta, Susmita, Benoit Laplante, and Nlandu Mamingi. 2001. "Pollution and Capital Markets in Developing Countries." Journal of Environmental Economics and Management 42 (3): 310-35.

Delarue, Erik, Kris Voorspools, and William D'haeseleer. 2008. "Fuel Switching in the Electricity Sector under the EU ETS: Review and Prospective." Journal of Energy Engineering 134 (2): 40-46.

-Ellerman, A. Denny, and Barbara K. Buchner. 2008. "Over-Allocation or Abatement? A Preliminary Analysis of the EU ETS Based on the 2005-06 Emissions Data.” Environmental and Resource Economics 41 (2): 267-87.

Ellerman, A. Denny, and Paul L. Joskow. 2008. The European Union's Emissions Trading System in Perspective. Pew Center for Global Climate Change. Cambridge, MA, May. 
Ellerman, A. Denny, Paul L. Joskow, Richard Schmalensee, Juan-Pablo Montero, and Elizabeth M. Bailey. 2000. Markets for Clean Air: The U.S. Acid Rain Program. Cambridge, UK: Cambridge University Press.

-Fama, Eugene F., Lawrence Fisher, Michael C. Jensen, and Richard Roll. 1969. "The Adjustment of Stock Prices to New Information.” International Economic Review 10 (1): 1-21.

Fisher-Vanden, Karen, and Karin S. Thorburn. 2011. "Voluntary corporate environmental initiatives and shareholder wealth." Journal of Environmental Economics and Management 62 (3): 430-45.

Goulder, Lawrence H., Marc A. C. Hafstead, and Michael Dworsky. 2010. "Impacts of alternative emissions allowance allocation methods under a federal cap-and-trade program." Journal of Environmental Economics and Management 60 (3): 161-81.

Gray, Wayne B. 1987. "The Cost of Regulation: OSHA, EPA and the Productivity Slowdown." American Economic Review 77 (5): 998-1006.

Gray, Wayne B., and Ronald J. Shadbegian. 1998. "Environmental Regulation, Investment Timing, and Technology Choice." Journal of Industrial Economics 46 (2): 235-56.

Greenstone, Michael. 2002. "The Impacts of Environmental Regulations on Industrial Activity: Evidence from the 1970 and 1977 Clean Air Act Amendments and the Census of Manufactures." Journal of Political Economy 110 (6): 1175-1219.

Kahn, Shulamit, and Christopher R. Knittel. 2002. "The Impact of the Clean Air Act Amendments of 1990 on Electric Utilities and Coal Mines: Evidence from the Stock Market.” University of California Energy Institute Working Paper CSEM WP 118.

Kettner, Claudia, Angela Köppl, Stefan P. Schleicher, and Gregor Thenius. 2008. "Stringency and distribution in the EU Emissions Trading Scheme: first evidence." Climate Policy 8 (1): 41-61.

Linn, Joshua. 2006. "Stock Prices and the Cost of Environmental Regulation." Center for Energy and Environmental Policy Research (CEEPR) 06-011.

Linn, Joshua. 2010. "The effect of cap-and-trade programs on firms' profits: Evidence from the Nitrogen Oxides Budget Trading Program.” Journal of Environmental Economics and Management 59 (1): $1-14$.

List, John A., Daniel L. Millimet, Per G. Fredriksson, and W. Warren McHone. 2003. "Effects of Environmental Regulations on Manufacturing Plant Births: Evidence from a Propensity Score Matching Estimator." Review of Economics and Statistics 85 (4): 944-52.

List, John A., Daniel L. Millimet, and W. Warren McHone. 2003. "The Unintended Disincentives in the Clean Air Act." B. E. Journal of Economic Analysis and Policy 3 (2): Article 2.

MacKinlay, A. Craig. 1997. "Event Studies in Economics and Finance." Journal of Economic Literature 35 (1): 13-39.

Oberndorfer, Ulrich. 2009. "EU Emission Allowances and the stock market: Evidence from the electricity industry." Ecological Economics 68 (4): 1116-26.

Petersen, Mitchell A. 2009. "Estimating Standard Errors in Finance Panel Data Sets: Comparing Approaches." Review of Financial Studies 22 (1): 435-80.

-Puller, Steven L. 2006. "The strategic use of innovation to influence regulatory standards." Journal of Environmental Economics and Management 52 (3): 690-706.

- Ryan, Stephen P. 2012. "The Costs of Environmental Regulation in a Concentrated Industry." Econometrica 80 (3): 1019-61.

-Salinger, Michael. 1992. "Standard Errors in Event Studies." Journal of Financial and Quantitative Analysis 27 (1): 39-53.

Salop, Steven C., and David T. Scheffman. 1983. "Raising Rivals' Costs." American Economic Review 73 (2): 267-71.

Seade, J. 1985. "Profitable Cost Increases and the Shifting of Taxation: Equilibrium Responses of Markets in Oligopoly." University of Warwick Department of Economics Working Paper 260.

Sijm, Jos, Karsten Neuhoff, and Yihsu Chen. 2006. " $\mathrm{CO}_{2}$ cost pass-through and windfall Profits in the power sector." Climate Policy 6 (1): 49-72.

-Smale, Robin, Murray Hartley, Cameron Hepburn, John Ward, and Michael Grubb. 2006. "The impact of $\mathrm{CO}_{2}$ emissions trading on firm profits and market prices." Climate Policy 6 (1): 31-48.

-Veith, Stefan, Jörg R. Werner, and Jochen Zimmermann. 2009. "Capital market response to emission rights returns: Evidence from the European power sector." Energy Economics 31 (4): 605-13.

Weiner, Christian. 2005. "The Impact of Industry Classification Schemes on Financial Research." Humboldt-Universität School of Business and Economics SFB 649 Discussion Paper 2005-062. 
This article has been cited by:

1. Natalia Fabra, Mar Reguant. 2014. Pass-Through of Emissions Costs in Electricity Markets. American Economic Review 104:9, 2872-2899. [Abstract] [View PDF article] [PDF with links]

2. Ralf Martin, Mirabelle Muûls, Laure B. de Preux, Ulrich J. Wagner. 2014. Industry Compensation under Relocation Risk: A Firm-Level Analysis of the EU Emissions Trading Scheme. American Economic Review 104:8, 2482-2508. [Abstract] [View PDF article] [PDF with links] 